\title{
O CIRCO COLORIDO
}

Bruna da Silva

Elizete Ruschel

\subsection{Senhoras e senhores, respeitável público, com vocês... o Grupo IV!}

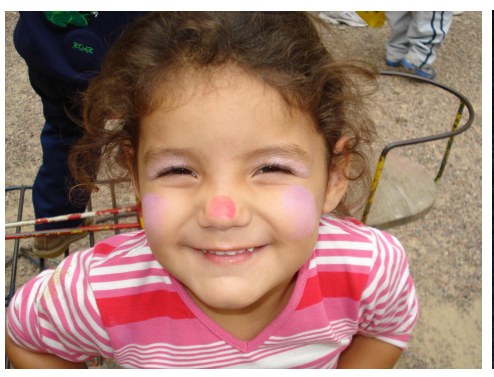

ANA

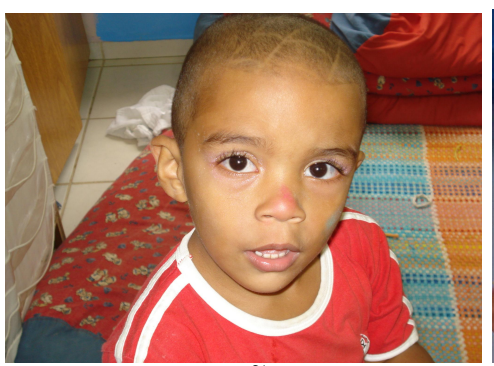

JOÃO

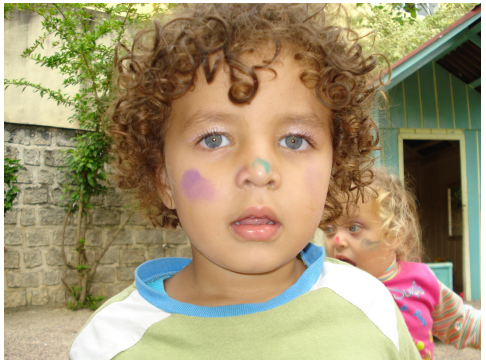

KAUAN CARLOS

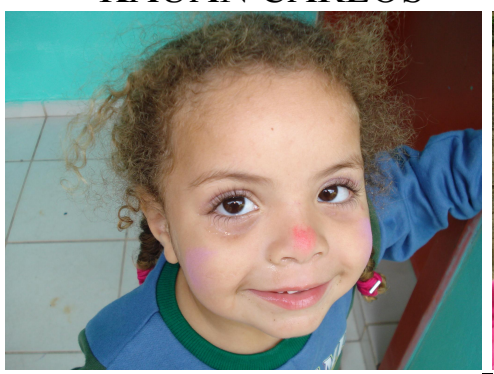

MARIA EDUARDA

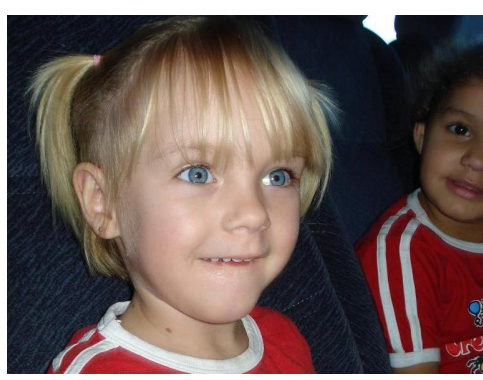

EMILY

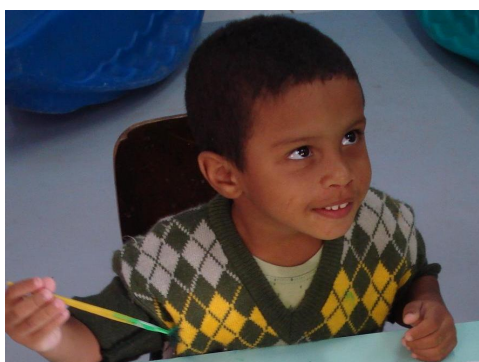

JUAN

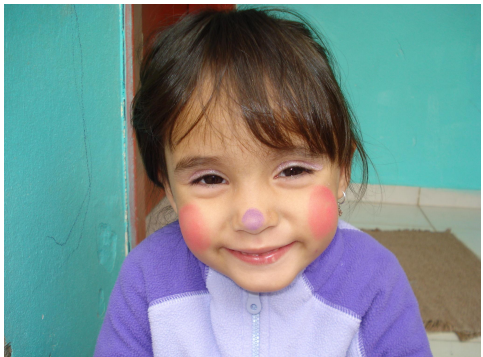

KAYLANE

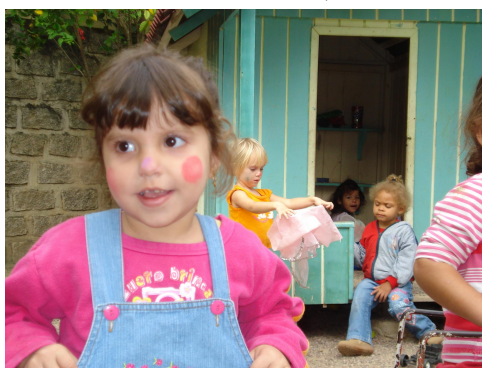

MARIELLA

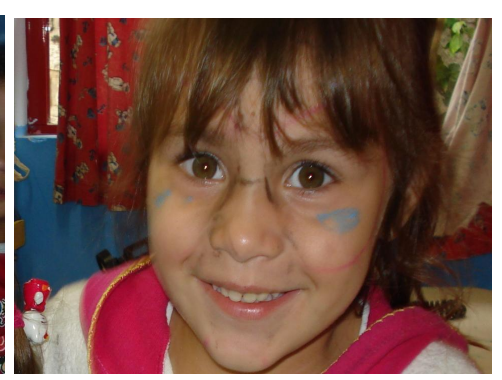

INGRID

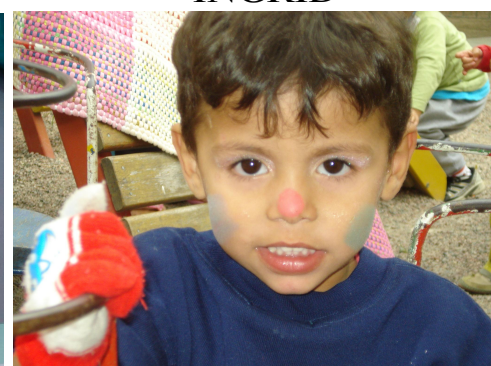

KAUÃ

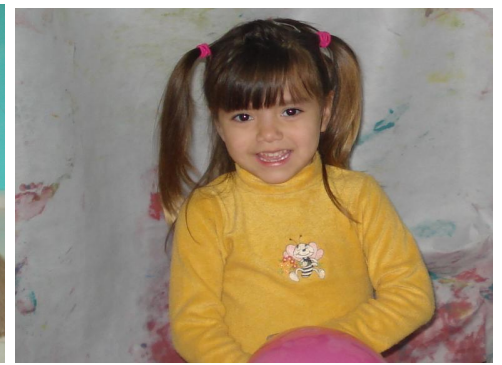

MANUELA

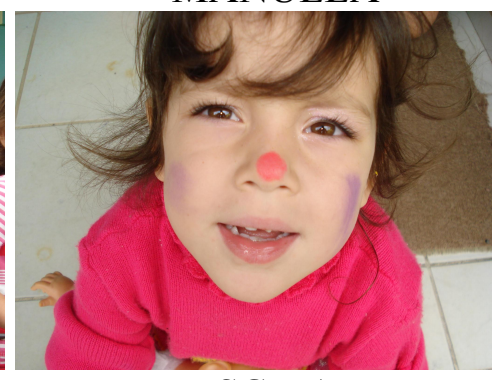

PRISCILA 


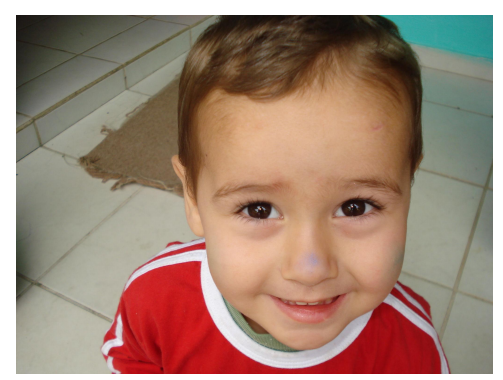

SAMUEL

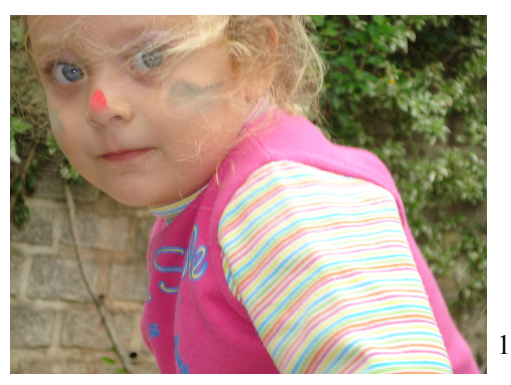

YASMIN

O Grupo IV (GIV) é formado por quinze crianças bastante distintas e alegres. Quando matriculadas essas crianças possuem o direito de comparecerem na instituição por período integral, o que normalmente acontece. $\mathrm{Na}$ creche os grupos são separados por faixa etária, as crianças desse grupo possuem idade entre três e quatro anos. A maioria dessas é moradora do bairro Agronômica, onde se encontra a creche. Têm em sua sala duas educadoras formadas em pedagogia.

Durante o tempo do sono, as crianças do GIV dividem a sala com crianças do GIII, sendo uma utilizada para as que querem dormir e outra para as que preferem brincar, ou vão aos poucos acordando. Assim, enquanto algumas crianças dormem na sala do GII, as outras brincam na sala do GIV.

$\mathrm{Na}$ sala, as mochilas das crianças ficam penduradas na parede, ao alcance das mesmas. Também na altura delas, encontra-se uma espécie de mural, feito de pano, que serve para fazer a chamada das crianças. Nesse mural há bolsos, onde ficam fichas com desenhos de animais, abaixo do desses, o nome de cada criança, de modo que cada animal representa uma criança. Quando uma criança falta, sua ficha fica virada para parede.

A sala tem prateleiras, onde ficam guardados alguns materiais para atividades e algumas caixas com brinquedos, esses ficam dispostos na sala, ao alcance das crianças. Também há um espelho pendurado na parede, na altura das crianças. Numa outra parede ainda, encontra-se um quadro negro, que muitas vezes é utilizado para expor os trabalhos das crianças.

O espaço da sala foi modificado muitas vezes durante o tempo em que tivemos na instituição, sempre com cantinhos, e brinquedos nas estantes e prateleiras na altura das crianças. Nesta sala há dois tapetões, um em cada canto, onde são contadas as histórias, cantadas músicas, além de servirem como espaços para as crianças brincarem

\footnotetext{
${ }^{1}$ Para completar as quinze crianças, faltou a foto de Letícia, essa freqüenta a creche apenas no período da manhã, nos impossibilitando tirar foto dela.
} 
e dormirem. Um canto reservado da sala, fechado por móveis, se torna uma espécie de cabana, onde estão dispostas algumas fantasias e acessórios.

Organizadas pela sala, de acordo com as necessidades de cada atividade, estão quatro mesas pequenas, cada uma com quatro lugares, e ao lado da porta de entrada, há uma mesa grande, que é usada pelas educadoras. A disposição dos objetos da sala é modificada de acordo com as necessidades de cada atividade.

O banheiro das crianças está anexado a sala, com vasos sanitários ideais para o tamanho delas, e com sabonetes pendurados em saquinhos de rede, para não gasta-los por ficarem caídos na água e também para evitar que caiam na sujeira. Este banheiro é dividido com o GIII, pois se encontra entre as duas salas, fazendo uma ligação entre elas.

Os horários de higiene, alimentação e sono, são sempre os mesmos, sendo que as atividades devem respeitar esses tempos, dando a entender, que a rotina é assim elaborada para não prejudicar o trabalho dos funcionários.

\subsection{A importância de um tema flexível}

Trabalhar com crianças pequenas requer comprometimento e respeito. Assim, para assumirmos essa postura durante a intervenção, nossa maior preocupação era o de fazer um plano com atividades que contemplassem as necessidades e os direitos das crianças. Para isso, procuramos não nos prender muito a um tema, propondo-nos a pensar num projeto que fosse suscetível a mudanças, tomando-o assim, como um condutor das atividades. Desse modo, o nosso tema gerador está relacionado à alegria, à brincadeira e à interação, e teve como título "Circo Colorido". Foi solicitado pela professora uma temática relacionada ao circo, a qual pediu que trabalhássemos as cores e forma para dar continuidade ao seu projeto.

Apesar de termos um tema predefinido, entendemos que esse não tem uma duração fixa, podendo variar segundo a sua abrangência, também ao interesse e as necessidades das crianças, que se explicitaram durante a observação da primeira etapa do estágio. Nesta observação, percebemos a curiosidade e a vontade das crianças em aprender novas brincadeiras, a disposição e alegria em realizar trabalhos artísticos, tais como a pintura, a modelagem com massinha colorida, dentre outras. 
Tendo o intuito de não ficar limitado pelo tema, buscamos pesquisar sobre o mesmo, considerando as inúmeras possibilidades existentes nos diversos espaços dentro e fora da instituição, que podem favorecer a ampliação das experiências e conhecimentos do grupo. Assim, como ressalta Ostetto (2002), para que o tema não se torne uma "camisa de força", a primeira preocupação deve ser: os conhecimentos envolvidos, o questionamento da criança, sua pesquisa e exploração, e não a realização da atividade.

Com as pistas apresentadas pelas crianças e os resultados das pesquisas, organizamos as possíveis atividades a serem realizadas durante a nossa intervenção, incluindo também atividades que não tratam necessariamente de circo, mas que envolviam as cores e as formas, a arte e brincadeiras. Tendo em mente que o planejamento seria flexível, podendo incluir ou excluir algumas atividades, de acordo com as necessidades e interesses demonstrados pelas crianças, no momento da sua realização, ou até mesmo pelos fatores externos, como chuva, frio, calor etc. Confirmando as idéias de Ostetto (2002), Kramer (1994, p. 59) ressalta que:

Um critério que se mostra importante no desenvolvimento do tema é, portanto, o de se conseguir levar em consideração os interesses do grupo enquanto coletivo e, simultaneamente, os interesses emergenciais de uma ou mais crianças. Permitir, então, a demonstração por parte das crianças de seus interesses, mesmo que desvinculados do tema, aproveitando situações inesperadas e não planejadas, é uma atitude fundamental para que não se faça do tema uma "camisa-de-força" e para que dele possa surgir (ou não) novos temas. O manejo progressivo dessa estratégia vai possibilitando a flexibilidade necessária para que sejam desenvolvidos outros temas a partir de um certo tema gerador, o que confere ao trabalho escolar o seu verdadeiro caráter dinâmico e vivo.

Desse modo, durante a nossa intervenção, algumas atividades deixaram de ser realizadas, sendo substituídas por outras, ou também, realizadas em locais diferentes do planejado. Assim, houve momentos, que em decorrência da chuva algumas atividades tiveram que ser feitas na sala, e outros ao ar livre para aproveitar o sol. Desse modo, todo o planejamento teve que ser repensado durante o tempo de intervenção, o que implicou em escolhas, que foram pautadas nas reações das crianças, nas indicações das mesmas. Muitas mudanças ocorreram, também, pela organização do tempo da instituição, o que muitas vezes impossibilitou a realização da atividade conforme o planejado. 
Assim sendo, consideramos que as mudanças feitas no plano de ensino são resultado da reflexão sobre a prática, sendo que, um planejamento rígido, não respeita a criança, pois, não considera as manifestações da mesma, tornando-se assim, apenas uma listagem de atividades, feita para preencher o tempo das crianças. Nesse sentido Ostetto (2002, p. 178) pondera que:

\begin{abstract}
A questão não é a forma, mas os princípios que sustentam uma ou outra organização. Sem dúvida, a elaboração de um planejamento depende da visão de mundo, de criança, de educação, de processo educativo que temos e que queremos: ao selecionar um conteúdo, uma atividade, uma música, na forma de encaminhar o trabalho. Envolve escolha: o que incluir, o que deixar de fora, onde e quando realizar isso ou aquilo. E as escolhas, a meu ver, derivam sempre de crenças ou princípios. Como um processo reflexivo, no processo de elaboração do planejamento o educador vai aprendendo e exercitando sua capacidade de perceber as necessidades do grupo de crianças, localizando manifestações de problemas e indo em busca das causas. Vai aprendendo caracterizar o problema para, ai sim, tomar decisões para superá-lo. $\mathrm{O}$ ato de planejar pressupõe o olhar atento à realidade.
\end{abstract}

Fazer um planejamento para crianças necessita de constante atenção para perceber o que elas revelam durante as atividades, sendo que assim, inevitavelmente as mudanças são necessárias, para que se considere a criança como um ser "[...] capaz de agir e interagir, de produzir cultura e de ser sujeito de direitos". (Machado, 2004, p. 8)

O planejamento também foi modificado, devido às oportunidades que surgiram no decorrer da nossa intervenção. Por exemplo, o passeio ao CIC, que não estava no planejamento, e tratava-se de uma exposição que ocorria na semana de nossa intervenção. Então pensando no que contribuiria mais para as crianças, decidimos retirar algumas atividades do nosso planejamento, para fazer tal passeio, pois este tinha ligação com o mesmo. Por este motivo que temos que refletir e avaliar sobre o que há de mais significativo para as crianças, sobre o que irá contribuir mais para a ampliação do conhecimento delas. Com isso, mostramos a necessidade de efetuarmos constantes pesquisas e ficarmos atentas aos atuais acontecimentos que possam contribuir para o projeto em curso. 


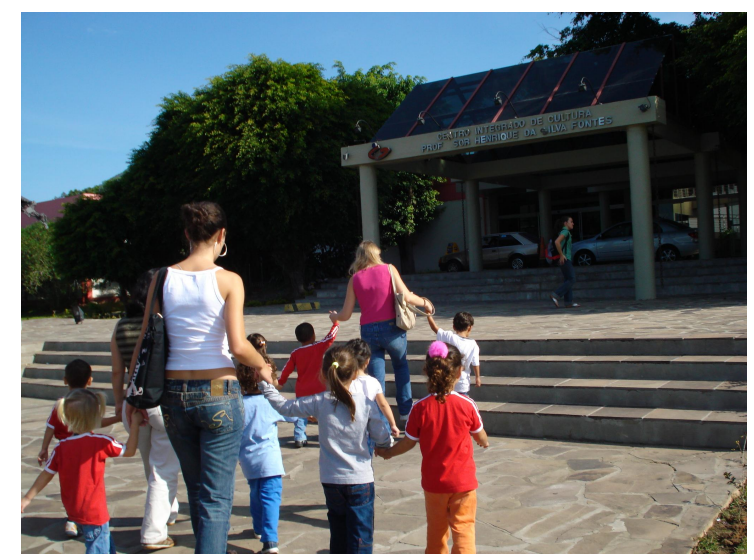

Chegando ao CIC, em 20 de maio de 2008.

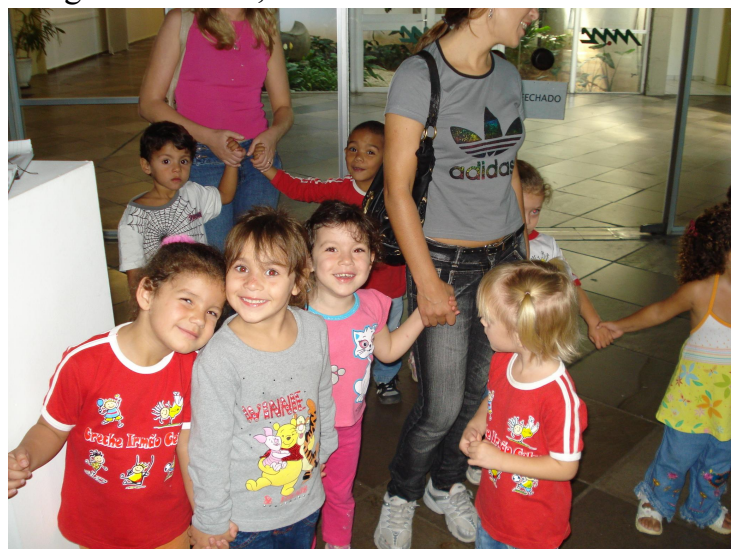

CIC, 20/05/08.

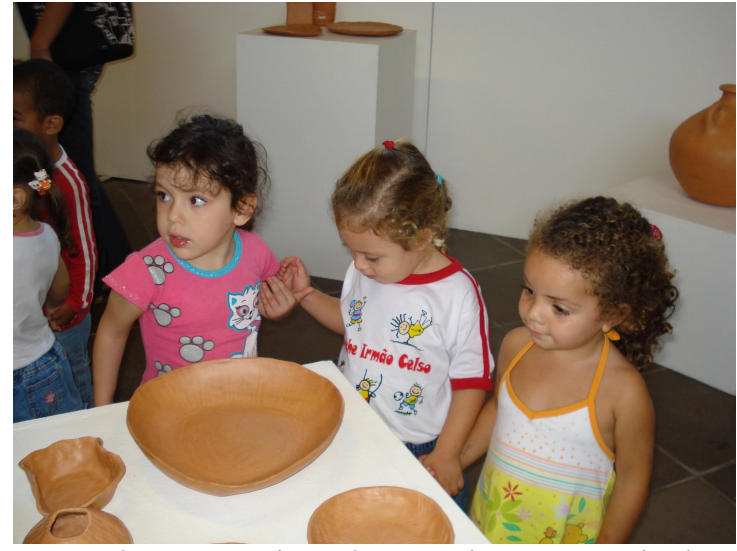

Passando na exposição de cerâmica, CIC, 20/05/08.

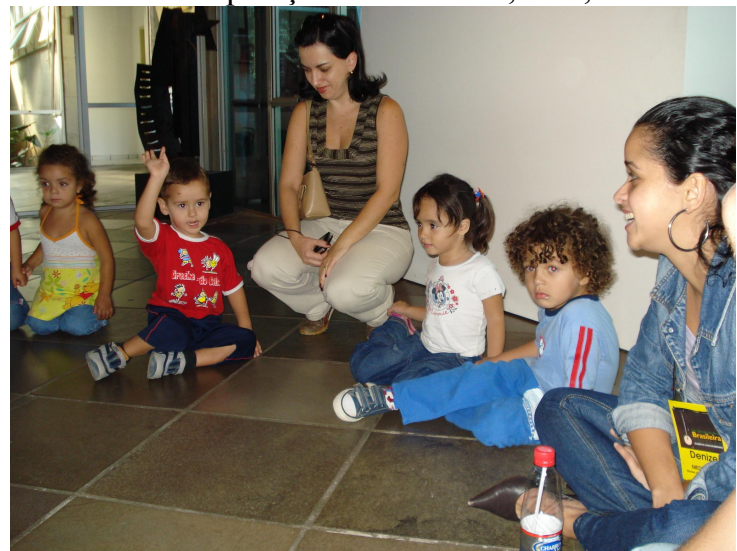

Conversando sobre a mostra, CIC, 20/05/08 

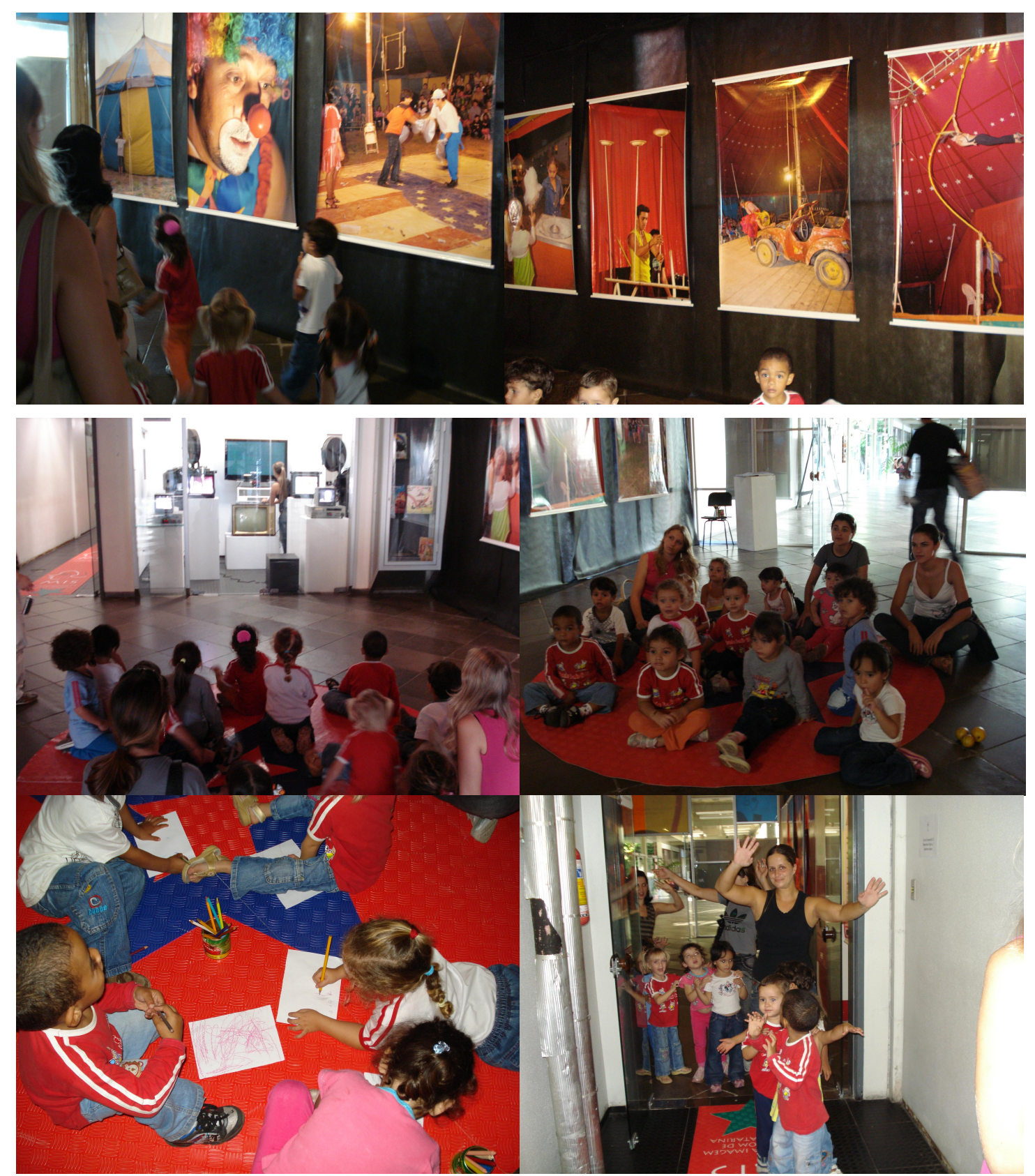

Na mostra "O mundo mágico do circo", no CIC-MIS, em 20 de maio de 2008.

Outra atividade que decidimos fazer, depois do planejamento pronto, foi levar as crianças à feira, para comprar as frutas e fazer uma salada, pois acreditamos que tal atividade ficaria muito mais significativa se as crianças passassem por todas as etapas. 


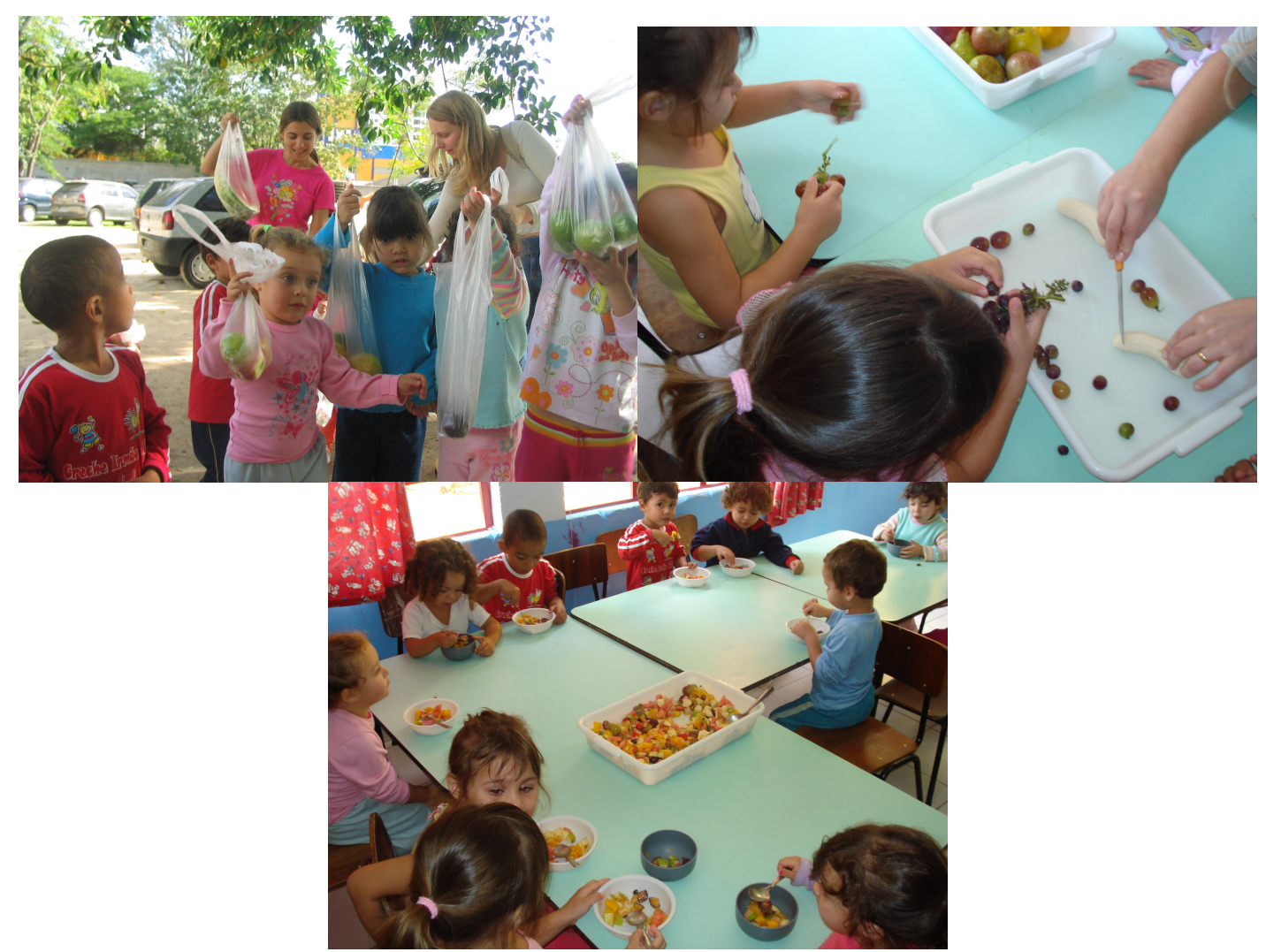

Preparando a salada de frutas, em 12 de maio de 2008.

Como nossas atividades foram escolhidas a partir de aspectos sociais e culturais, decidimos explorar também, o contexto exterior à instituição, para proporcionar, de maneira coletiva, uma ampliação de conhecimento e experiência para as crianças. Segundo Kramer (1994, p. 58),

Isso significa considerar as imensas e inúmeras possibilidades que o contexto exterior à escola oferece, não só em termos de museus, teatros, cinema e exposições disponíveis, mas também dos serviços e situações existentes, tais como o correio, a feira, o supermercado, a fabrica e outras instituições.

Assim, buscamos um planejamento todo direcionado para as crianças, a partir de pistas que elas nos deram durante nossas observações. E durante a aplicação desse, não deixamos de continuar pesquisando e refletindo sobre maneiras de melhora-lo para que cada momento fosse muito significativo para as crianças. 


\subsection{A atividade definindo o tempo ou o tempo definindo a atividade?}

$\mathrm{Na}$ sociedade industrial, as pessoas passaram a viver sob a lógica do capitalismo, em que o tempo encontra-se relacionado com a produção, assim, entende-se que "tempo é dinheiro". A educação não escapa à essa lógica, posto que em determinados discursos a preocupação está em preparar a criança para o mercado de trabalho, assim, elas passam a ser vistas como produtoras e consumidores em potencial. Além disso, passa-se a valorizar na educação infantil, apenas o tempo utilizado para atividades que resultam em produções, as quais podem ser mostradas aos seus responsáveis, para que possam provar que não estão "perdendo tempo", e sim preparadas para terem futuros êxitos no ensino fundamental. A citação abaixo, mesmo utilizando a palavra escola, explicita essa idéia, sendo que tal postura em relação ao tempo, também é assumida na educação infantil.

[...] a vida das pessoas passou a depender exclusivamente da exigência da produção, criando-se uma ditadura do relógio que muitas vezes nos impossibilita vivenciar outras coisas fora do contexto do trabalho. Dessa forma, a reificação aflora e ocorre o massacre do cotidiano. Já não somos donos da nossa vida, do nosso tempo, pois acreditamos que fora do processo de produção tudo que fazemos é 'perder tempo', é realizar atividades improdutivas, como se a vida se resumisse apenas na lógica estabelecida pela sociedade. Tal postura espalha-se nas principais instituições sociais, entre elas, a escola. (SERRÃO, 2003, p. 27)

O que costumamos ver nas instituições é a organização do tempo determinando as atividades, o que faz com que essas sejam quebradas muitas vezes, causando o desinteresse das crianças pela continuação, fazendo com que as atividades percam seu foco.

$\mathrm{Na}$ instituição que estagiamos, na parte da tarde, as atividades são interrompidas por duas refeições, o lanche e a janta, fazendo com que as outras atividades aconteçam em função do tempo que sobra. Em vez de nos concentrarmos nas atividades, ficamos o tempo todo olhando o relógio, preocupados com a hora das refeições, para que as crianças não percam tais horários. Assim, a criança já começa a viver conforme a lógica industrial capitalista, que tem que cumprir horários, como se tivessem sendo preparadas para o futuro, e perdendo os momentos importantes do presente. 
Mesmo sabendo da importância de valorizar a atividade em si, e não o tempo levado para realizá-la, isso se tornou impossível em nossa prática, pois se não levássemos as crianças para as refeições, ficariam com fome depois, ou teriam que comer a comida fria, atrapalhando a rotina das merendeiras e faxineiras, que têm horários para cumprir.

Já no começo de nossa intervenção, sentimos a necessidade de mais tempo para realizar a atividade da pintura com êxito, pois no momento em que as crianças estavam mais envolvidas com a atividade, tivemos que interromper para arrumá-las para irem jantar, nos obrigando a limpar as crianças de forma apressada, não podendo vivenciar o banho como um momento de interação.
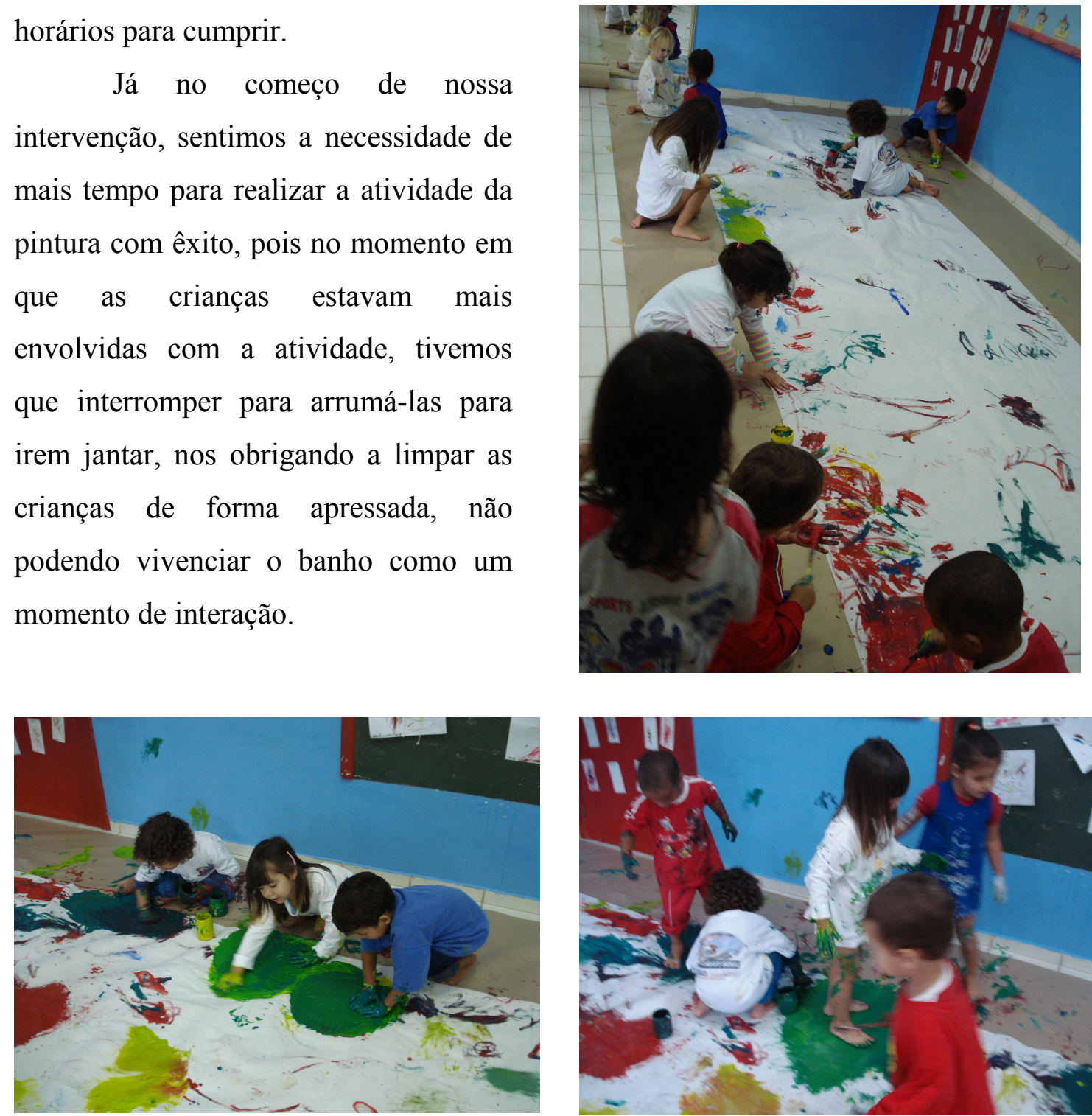

Pintando o grande tecido, para tenda, em: 29 de abril de 2008.

Em outros momentos, como o que aconteceu em um dos dias do nosso planejamento, em que compraríamos frutas, para preparar uma salada com a ajuda das crianças, para, em seguida, na hora do lanche, fazer um piquenique no parque grande, onde também, seria realizada a atividade da argila. Mas, pela falta de tempo, e por considerarmos ser mais significativo as próprias crianças comprarem frutas, ficamos com pouco tempo para as outras atividades planejadas, pois essas seriam mais uma vez interrompidas pela janta. Tivemos que decidir comer as frutas na sala, deixando o 
piquenique para outra aula, para poder realizar a atividade da argila, na qual acreditamos ser mais interessante naquele dia de sol.

Autores como Serrão (2003) e Batista (2003) mostram a importância de realizar as atividades a fim de que essa determine o tempo necessário para que possam ser aproveitadas ao máximo, respeitando o ritmo de cada grupo. Nesse sentido, segue Serrão (2003, p. 28),

A rotina na educação infantil não pode ser maçante, tediosa, cerceadora. É necessário ampliarmos o conceito de rotina e compreendê-la como 'a expressão do pulsar do coração (com diferentes batidas rítmicas) vivo do grupo. (...) uma cadência seqüenciada de atividades, que se desenvolvem num ritmo próprio, em cada grupo' (FREIRE, 1998, p. 43). Considerar o ritmo como elemento constitutivo da rotina traz a possibilidade de nos libertarmos. Deixando de ser escravos do relógio e da produção.

Muitas vezes, tivemos que interromper a atividade para ir para o lanche ou jantar, bem no momento em que as crianças tinham acabado de se envolver efetivamente, pois, nesses momentos podíamos perceber em suas expressões a alegria em realizá-las.

O tempo na creche não pode ser rígido, pois isso homogeneíza as crianças, e não respeita o tempo que cada uma precisa para vivenciar plenamente cada momento. Para isso todos os funcionários da instituição precisam estar cientes da importância de horários flexíveis.

\subsection{Explorando os espaços}

O espaço utilizado pelas crianças na creche foi algo que ficou muito marcado em nossas vivências na instituição. Percebemos que a organização dos espaços tem influência direta sobre as pessoas que nele atuam. E as formas com que as crianças utilizavam e reutilizavam os espaços nos mostrou o que elas sentem em determinas atividades, fazendo com que pensássemos a organização dos espaços, de forma a respeitar as suas necessidades.

A instituição que atuamos, traz em sua organização, um modelo que separa os grupos de crianças, por faixa etária. Durante o tempo que tivemos na creche, 
percebemos que cada grupo tem um limite de espaços, predefinido para cada atividade. Por exemplo: o GI fica limitado à sala; o GII à sala e algumas vezes ao parque pequeno; o GIII à sala, ao parque pequeno e ao refeitório; o GIV limitasse aos mesmos espaços que o GIII; o GV à sala, ao refeitório e ao parque grande; e o GVI aos mesmos espaços que o $\mathbf{G V}$.

Durante nossa intervenção, as atividades que utilizaram espaços que não fazem parte da rotina ${ }^{2}$ do $\mathbf{G I V}$, fizeram com que as crianças ficassem dispersas, mostrando maior interesse em explorar o espaço já conhecido por elas, porém pouco utilizado.

\section{$\underline{\text { Situação } 1}$}

Levamos as crianças para a briquedoteca, colocamos colchonétes no chão e demos as capas e esponjas para as crianças encherem enquanto assistíamos ao DVD. Foi a maior festa com as esponjas, as crianças começaram a tirar as esponjas do saco e jogar para cima, algumas queriam ver o DVD enquanto umas brincavam com as esponjas e outras enchiam as capas. Logo as crianças se desinteressaram pela atividade, ficando dispersas, andando pelo corredor, indo para a sala. Então, voltamos para sala e deixamos elas brincarem no parque pequeno até a hora da janta. (Relatório de intervenção GIV, 06/05/2008)

\footnotetext{
${ }^{2}$ Utilizaremos aqui a concepção de rotina trazida por Barbosa (2006, p. 35), "Rotina é uma categoria pedagógica que os responsáveis da educação infantil estruturam para, a partir dela, desenvolver o trabalho cotidiano nas instituições de educação infantil."
} 


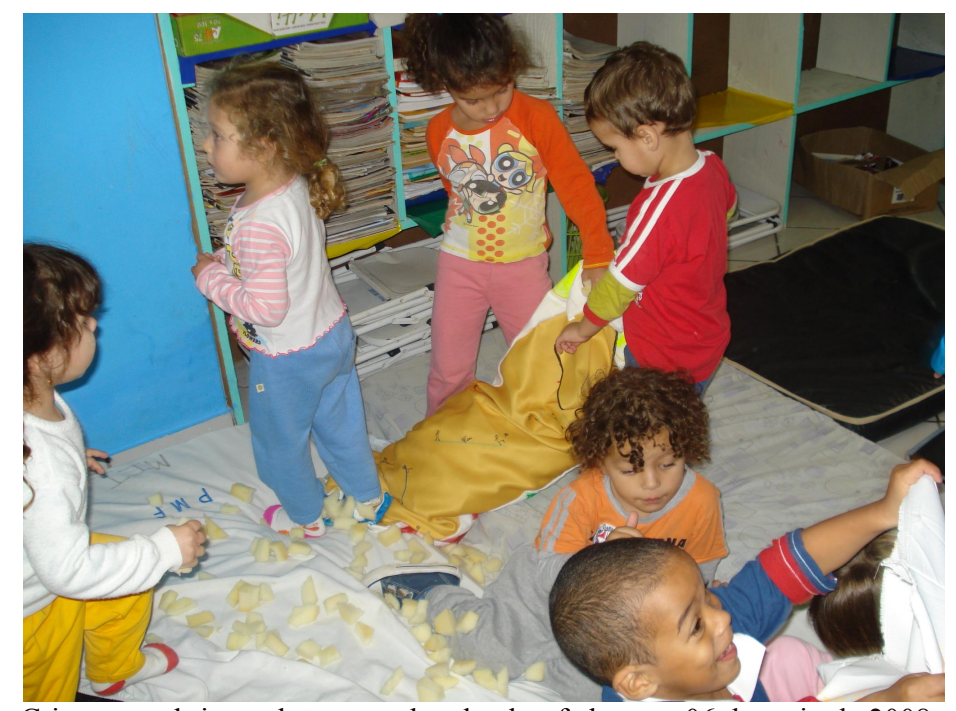

Crianças na brinquedoteca, enchendo almofadas, em 06 de maio de 2008.

\section{Situaç̃̃o 2}

As crianças começaram a mexer na argila e não sabiam usar aquele material, explicamos que era parecido com massinha e que elas poderiam fazer qualquer tipo de objetos, dando exemplos a elas e ainda fazendo junto. As crianças brincaram pouco tempo, pois o espaço do parque lhes chamava mais atenção, já as crianças, de outros grupos, que estavam no parque quiseram brincar com a argila. Do GIV apenas quatro crianças ficaram concentradas e fizeram objetos com a argila, junto com crianças de outros grupos. Mariella foi a única que ficou brincando com a argila até a hora de irmos para sala. Antes de entrar na sala, as crianças que não quiseram brincar com argila no parque grande, pediram para brincar com argila no parque pequeno, na hora de entrar na sala para jantar. (Relatório de intervenção GIV, 12/05/2008) 

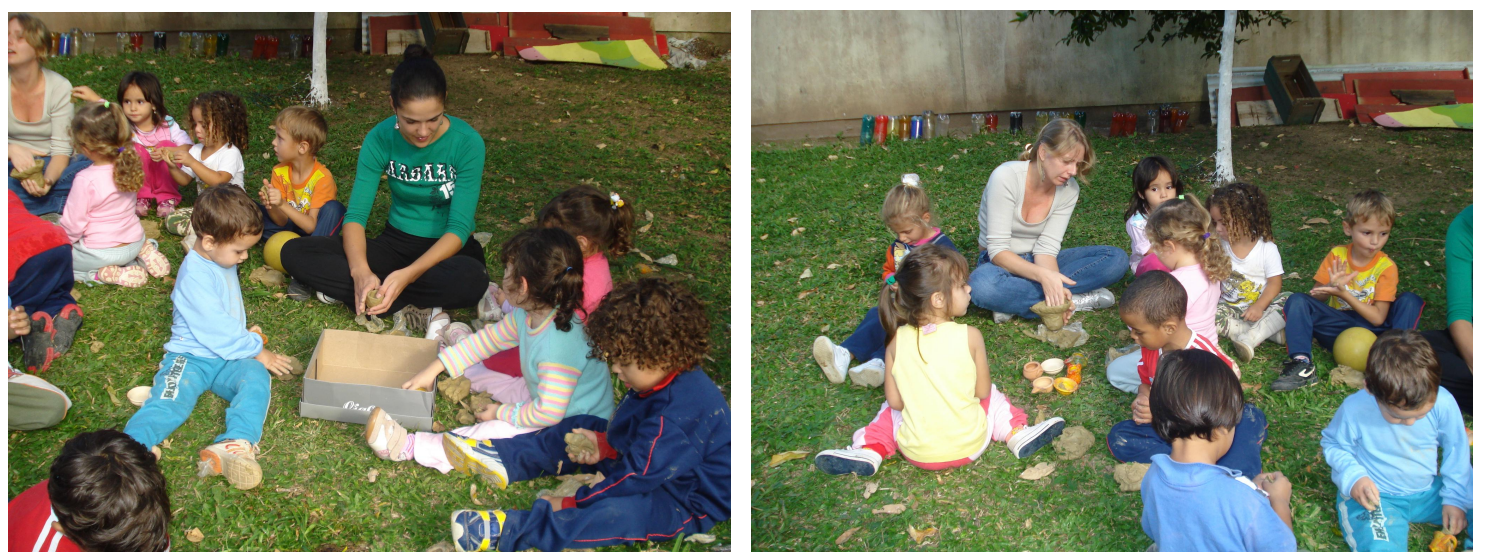

Brincando com argila no parque grande, em 12 de maio de 2008.

Nas situações descritas acima, podemos perceber que os ambientes chamaram mais atenção das crianças do que as atividades propostas. Acreditamos que isso aconteceu pelo fato de as crianças conhecerem tais lugares, mas de o terem vivenciado poucas vezes, tirando, assim, a atenção delas, que demonstravam grandes desejos por explorar aqueles espaços.

Na situação 1, as crianças acharam mais interessante andar pelos corredores, coisa que fazem quando tem alguma finalidade, como chegada e saída, ir ao refeitório comer e passar para fazer alguma atividade, então, na hora que propomos a atividade elas adoraram, porém fazer algo que geralmente não fazem se tornou mais interessante.

$\mathrm{Na}$ situação 2, fica mais claro ainda essa vontade que as crianças sentem de explorar os locais que são delas e onde estão pouco presente. As crianças do GIV deixaram de brincar com argila para brincar no parque grande, pouco freqüentado por elas, porém os grupos das crianças de mais idade que têm o parque grande como algo comum, preferiram brincar com a argila, concentrando-se na atividade.

Por isso os espaços não podem ser limitados, separando o que cada idade pode ou não, todas as crianças que fazem parte da instituição têm o direito de explorar e vivenciar todos os espaços que fazem parte, pois são delas. Assim, em qualquer espaço que realizarmos uma atividade, as crianças poderão se concentrar nessa, sabendo que poderão aproveitar aquela atividade, pois terão oportunidade de vivenciar os espaços em outros momentos.

Em algumas ocasiões, como nas situações descritas, deixamos que as crianças escolhessem a atividade que mais lhes chamavam atenção, pois partimos do pressuposto de que elas têm suas necessidades próprias. Então, ao invés de repreender as crianças e obrigá-las a trabalharem conforme as atividades que planejamos, deixamos que 
brincassem, pois consideramos que naquele momento, desfrutar aqueles espaços era mais importante para elas do que desenvolver a atividade proposta por nós. Sobre esse assunto Agostinho (2005, p. 66) ressalta que:

\begin{abstract}
A organização de espaços diversos e plurais rompe com a lógica do uniforme, igual, oportuniza vivencias heterogêneas para o grupo de crianças, distanciando-se de uma perspectiva homogeneizadora que prevê que todos façam a mesma coisa no mesmo tempo, rompendo assim com práticas adultocêntricas, e com os modelos escolares; respeita ritmos e escolhas pessoais, enriquecendo as práticas da educação infantil com atividades significativas e prazerosas para crianças e adultos.
\end{abstract}

Nesse sentido, como educadoras devemos desconfiar da harmonia, das práticas que pretendem que todos façam as atividades ao mesmo tempo, para isso, necessitamos de constante reflexão e uma postura critica em relação às próprias intervenções.

\title{
1.5 A Organização dos espaços
}

Pensando nas interações que podem ocorrer nos diferentes espaços, planejamos dois dias de visitas entre os bebês e as crianças do GIV. Assim, tanto a turma do GII, quanto a GIV, foi dividida em dois grupos, sendo que, uma parte das crianças de cada grupo visitaria a sala do outro, oportunizando a interação em espaços diferentes e também num espaço coletivo, que é o refeitório.

Fazer as trocas de sala, interagindo crianças com bebês, tornou-se muito interessante para percebermos como a organização do espaço pode influenciar as pessoas que nele convivem. Durante os dois dias de troca, percebemos que no GIV as crianças interagiram mais, e no GII as crianças ficaram brincando mais individualmente, causando até brigas por disputas de brinquedos.

O espaço do GII estava organizado de uma forma que parecia ter intenção de facilitar o desenvolvimento motor global dos bebês e também para protegê-los. Tinham poucos objetos ao alcance deles, brinquedos no alto das prateleiras, com espaços bem livres e a mesa de refeições para o lado de fora da sala. Percebemos que devido à grande quantidade de bebês nas salas, essa organização acaba sendo pensada de forma a facilitar o cuidado, sendo que as educadoras necessitam dar atenção a todos os bebês ao 
mesmo tempo. Porém, essa organização não contribui para autonomia das crianças, pois dependem do adulto para todas as atividades, dificultando também na interação entre elas.

Em várias creches, é comum encontrarmos um grande número de crianças pequenas para apenas um educador. É comum encontrarmos também espaços vazios com poucos móveis, objetos e equipamentos. Nesse contexto, geralmente observamos que a maioria das crianças fica muito em volta do educador, solicitando o tempo todo sua atenção. (CARVALHO \& MENEGHINI, 2002, p. 150).

Mesmo que muitos acreditem que o espaço aberto para os bebês brincarem, possa facilitar o trabalho das educadoras, essas autoras mostram que não, pois dessa forma as educadoras necessitam dar mais atenção para cada um, ficando mais ocupadas, pois sem cantinhos e brinquedos ao seu alcance, os bebês procuram mais os adultos para atenderem suas necessidades de brinquedos, não sobrando tempo para uma atenção mais individualizada, que faz com que as educadoras consigam perceber e conhecer cada criança individualmente.

Carvalho \& Rubiano (1995) ressaltam, que os bebês são capazes de envolver-se e manter-se em atividades, principalmente com os seus colegas, para isso necessitam de obstáculos para que sejam desafiadas, assim, devem ter a oportunidade de irem à busca dos brinquedos que desejam.

Nesse sentido, durante nossa intervenção, percebemos que os bebês ficaram bem à vontade e brincaram bastante na sala do GIV, explorando os espaços e os brinquedos que ficavam todos disponíveis. Além disso, procuravam ir aos espaços que continham mais obstáculos, como os cantinhos e a tenda, interagindo mais com as outras crianças.

Quanto às crianças do GIV, percebemos que elas não se sentiram à vontade no GII, pois a forma que o espaço estava organizado não atraia a atenção delas. As crianças possuem muitas idéias de brincadeiras e o espaço organizado daquela forma sem brinquedo ao alcance, não proporcionava nenhum tipo de fantasia, fazendo com que elas sentissem vontade de voltar para sala ou brigassem pelos poucos brinquedos e objetos disponíveis na sala. Vejamos então as situações descritas a baixo:

\section{Situação 1}

No GII apenas três brinquedos chamaram a atenção das crianças do GIV, fazendo que elas disputassem esses, elas 
gostaram do escorregador, da rede e de umas garrafas com água colorida parecidas com aquário. Algumas crianças até brigaram para brincar com o mesmo brinquedo, sendo que era novidade e tinha poucos do mesmo modelo. Em vários momentos as crianças mostraram vontade e pediram para voltar à sala. (Relatório de intervenção GIV, 13/05/08)

\section{Situação 2}

De volta a sala do GII, Priscila subiu num brinquedo que da para encaixar a parte do escorregador, para alcançar as prateleiras onde estavam bichos de pelúcia, João vai ajudá-la, subindo também no brinquedo. A educadora, presente na sala preocupada pede para eles descerem, mas eles continuam tentando alcançar os brinquedos. Ajudo-os a tirar os brinquedos de cima das prateleiras, fazendo o som que caracteriza cada bicho. Priscila começa a andar de quatro imitando um cachorro tentando envolver os bebês. Apenas um deles participa da brincadeira e logo desiste. (Relatório de intervenção GIV, 14/05/08)

Podemos perceber pelas duas situações que aquela organização do espaço da sala do GII, não contribuiu para a fantasia das crianças maiores, causando disputas e desinteresse pelo local. Agostinho (2005, p. 67) ressalta:

[...] a importância de planejar e organizar o espaço da instituição de educação infantil de forma que os meninos e meninas que ali passam parte do seu dia, em todos os dias durante a semana, tenham o seu direito à brincadeira garantido, com muitos e diversos brinquedos e que estes estejam acessíveis, inteiros, limpos, disponibilizados de forma criativa e convidativa.

É necessário propor espaços que contemplem as necessidades das crianças. Pois, este tem influência direta sobre ações delas. Assim, a organização dos espaços deve ser planejada para que as crianças sintam prazer em estar ali, e sintam-se estimuladas a criarem brincadeiras. Os espaços podem ser constantemente modificados, trazendo sempre, novos elementos para compor os espaços vivenciados pelas crianças, de forma 
que as essas se sintam acolhidas no ambiente, e possam promover a apropriação e reapropriação dos mesmos.

\subsection{As relações: criança-criança, criança-adulto e criança-espaço}

Partindo da reflexão de que as instituições de educação infantil são organizadas de forma a facilitar o trabalho dos adultos, e organizadas sob essa lógica, a grande maioria das creches separa os grupos de crianças baseados na faixa etária.

Nesse sentido, acreditamos que cabe aos professores, criar estratégias para a interação entre os diferentes grupos. Assim, considera-se que a creche é um lugar muito importante para o desenvolvimento da criança, pois lá elas têm contato com as outras crianças e com os adultos, nesta interação elas têm oportunidade de novas vivências, o que também possibilita a construção das culturas infantis. Segundo Wajskop (2001) "A brincadeira pode ser um espaço privilegiado de interação e confronto de diferentes crianças com diferentes pontos de vista.” (p.33).

Durante nosso estágio, percebemos que o GIII e GIV interagem com mais freqüência. Por exemplo, na hora do sono, em que as crianças dormem todas na mesma sala, e quando acordam, brincam juntas em outra sala. Também na comemoração dos aniversariantes do mês em que esses grupos fazem festa coletiva. Os demais grupos interagem em momentos como no parque e no fim do dia, quando uma das educadoras vai embora e ficam poucas crianças, então elas são reunidas numa única sala.

Não percebemos muita interação entre as crianças maiores e os bebês, e, assim, sentimos a necessidade de incluir essa interação no nosso planejamento. Pois, como nos mostra Ferreira (2004), na instituição de educação infantil a socialização não é vertical, as crianças não se socializam somente na interação com a professora, elas aprendem também na interação com outras crianças, com seus pares. Além de que “[...] misturar os agrupamentos em determinadas situações, possibilitando interações de crianças mais velhas e mais novas, é uma das maneiras de defender o direito à diversidade." (Machado, 2002, p.8). Esses são grandes motivos para proporcionarmos momentos de interação entre as crianças, deixando-as livres para escolherem seus pares. 
Nos dias da troca, tínhamos uma preocupação de que as crianças do GIV pudessem machucar os do GII, e assim tivemos o cuidado de conversar sobre isso com as crianças do GIV, como registramos no relatório:

Explicamos que, quem fosse para outra sala deveria respeitar os brinquedos de lá e brincar junto com as crianças, e também sobre os cuidados que deveriam ter com as crianças menores, principalmente no momento que iriam ajudar os bebês no jantar. (Relatório de intervenção GIV, 13/05/2008)

Percebemos, nestes dois dias, que a nossa preocupação foi desnecessária, pois, acreditamos que mesmo se não tivéssemos a conversa sobre os cuidados, isso se daria espontaneamente. Sendo que as crianças demonstraram perfeita noção de cuidado com os bebês, e que em nenhum momento alguém machucou o outro. Compreendemos assim, que essa é uma idéia preconceituosa, advinda de teorias etapistas, que enquadra todas as crianças em um lugar comum, de acordo com fases delimitadas, segundo as idades das crianças. Assim, Prado (2002) mostra em uma pesquisa de crianças pequenas, realizada em creches públicas brasileiras, que as crianças,

[...] transgrediam a divisão etária proposta no contexto da creche, aquela utilizada em todo o sistema escolar, que parte de uma concepção de infância como algo que se compartimentaliza em fases tão delimitáveis que, quase naturalmente, coloca às crianças um modelo definitivo e definidor na construção de seu desenvolvimento e de sua identidade social, reforçada pelas teorias etapistas de desenvolvimento infantil e por pré-noções em relação à infância, como por exemplo, que as crianças maiores machucam as crianças menores ou que crianças maiores e menores não sabem brincar juntas, dentre tantas outras. (Prado, 2002, p. 106).

Em algumas situações, em que as crianças do GIV tentavam ajudar os bebês, pegando na mão para conduzi-los, tentando arrumar o grampo do cabelo do bebê que estava caindo, ocasionava algumas vezes, o desconforto do bebê, pois não queria ser ajudado. Schmitt (2008) observa em sua pesquisa que:

De maneira geral os bebês se revelam alegres na presença de outras crianças que conversam com eles e os acariciam, mas expressam desconforto e recusa quando são demasiadamente tocados, abraçados e apertados. Da mesma forma que respondem com sorrisos 
receptivos à companhia das outras crianças, eles também recusam aquilo que os desagrada, pelo choro ou por manifestações de afastamento. (p.178)

Assim podemos ver na situação abaixo, a qual Kauã tentava cuidar da menina, ocorrendo um conflito entre eles, pois o bebê chorava para mostrar que não estava satisfeito com a situação, ele insiste e ela continua chorando para se fazer entender.

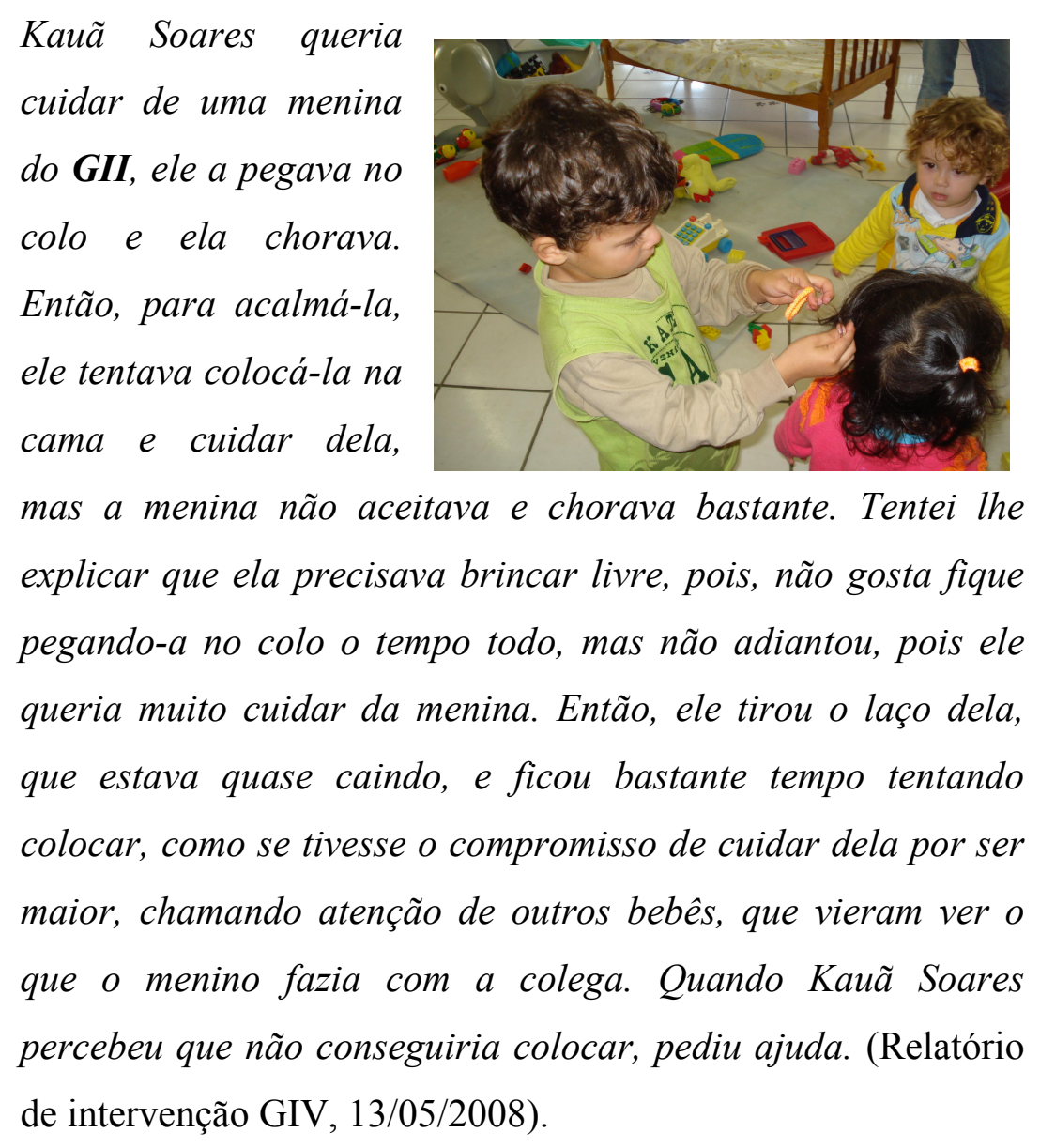

Percebemos que Kauã tentou achar uma maneira de ser aceito pela menina, já que ela não quis ser pega no colo, ele tentou cuidar dela de outras maneiras. Assim, percebemos que mesmo que as relações muitas vezes sejam conflituosas, as crianças aprendem muito nessa troca com seus pares. Neste sentido, as creches são locais ricos, de grande importância, para as crianças vivenciarem novas experiências. Nesse sentido, Ferreira $(2004$, p. 58) ressalta que,

[...] as crianças não se 'limitam' a reproduzir o mundo dos 'grandes' à sua escala mas, 'pelo avesso', o reconstroem e ressignificam através 
de múltiplas e complexas interacções com os pares, permite mostrálas não só como autoras das suas próprias infâncias mas também como actores sociais com interesses e modos de pensar, agir e sentir específicos e comuns, capazes de gerar relações e conteúdos de relação, sentido de segurança e de comunidade que estão na sua génese como grupo social.

Percebemos que havia certa resistência para a interação entre os diferentes grupos, talvez porque ainda não haviam construído uma relação entre eles, pela falta de hábito de proporcionar encontros entre os dois grupos. Isso ficava mais evidente na sala do GII, em que as crianças de cada grupo brincavam separadas, como nas duas situações relatadas abaixo:

\section{$\underline{\text { Situação } 1}$}

Ali tocava uma música num volume baixo, os brinquedos estavam nas prateleiras. Alguns bebês brincavam sozinhos e outros com a estagiária Illa, que convidou as crianças do GIV para brincarem junto, mas essas não se mostraram muito animadas. (Relatório de intervenção GIV, 14/05/2008)

\section{$\underline{\text { Situação } 2}$}

As crianças do $\boldsymbol{G I V}$ ficaram um pouco tímidas no começo, e olhavam tudo ao redor, aos poucos todas começaram a pegar os brinquedos e brincar com os próprios colegas de sala, não interagindo com os bebês. Os bebês olhavam surpresos toda aquela movimentação e continuavam com seus brinquedos e brincadeiras. (Relatório de intervenção GIV, 13/05/2008).

Para Ferreira (2004), a rotina é fundamental para que haja interação, e assim, se constitua o grupo, pois a identidade do grupo é construída a partir das brincadeiras conjuntas, em que são criadas regras Além disso, a autora considera que a rotina da cultura de pares "[...] não só possibilitam uma experiência de criança entre criança como, a fazê-lo lhes permite ultrapassar a lassidez do conjunto pela sua integração numa vida social de grupo, crescentemente normalizada e normatizada." (FERREIRA, 2004, p.66) 
A presença de um adulto muitas vezes contribuiu para incentivar a interação entre os diferentes grupos, como sugerir brincadeiras conjuntas ou pedir para que as crianças mostrassem o espaço da sala e os brinquedos, com a intenção de minimizar os constrangimentos iniciais. Podemos perceber no relato abaixo, que a intervenção do adulto pode contribuir para a interação entre as crianças:

Quando os bebês chegaram à sala, eu e a estagiária Camila, pedimos que as crianças do GIV apresentassem a tenda de circo e os brinquedos da sala para os bebês. Algumas crianças pegaram nas mãos dos bebês para mostrar-lhes a sala, mas os bebês estranharam, assim choravam e procuravam pela Camila. Colocamos um CD com músicas de circo e enchemos balões coloridos. As crianças começaram a brincar com os balões que jogávamos para cima, depois continuaram brincando com outros brinquedos. Como os bebês brincam mais individualmente, e interagem diferentemente das crianças maiores, convidamos todas as crianças para entrarem na tenda de circo, jogávamos os balões para dentro da tenda e as crianças brincavam. As crianças saiam e entravam na tenda, alguns bebês distraíram-se com os livros que estavam dispostos no cesto, outros ficavam brincando com brinquedos. (Relatório de intervenção GIV, 13/05/2008).

$\mathrm{Na}$ situação acima, foi fundamental a intervenção das estagiárias para dar um incentivo, para que as interações mais diretas pudessem acontecer, pois as crianças maiores demonstram maior autonomia, tomando as atitudes como conduzir os bebês, para mostrar-lhes a sala e os brinquedos. Porém, os bebês que não se sentiram à vontade, estranhando aquele novo espaço e crianças diferentes das quais tem um convívio mais direto, começam a chorar, para pedir a ajuda da Camila, que passa mais tempo com eles. Sobre esse assunto Schimitt (2008) ressalta que:

O choro aparece como uma das manifestações que mais provoca e contagia as relações no grupo. Geralmente é interpretado como sinal de urgência, e mobiliza tanto os profissionais como as demais crianças, que se contagiam. (p.187) 
No relato abaixo, a intervenção acontece no sentido de iniciar e incentivar brincadeiras entre as crianças das duas turmas, em que após iniciarem a brincadeira, elas continuam brincando sem a mediação dos adultos.

\section{Situaç̃̃o 1}

Com um balão, falei que ia lutar com o príncipe por que ele estava protegendo as princesas, dei um balão para ele e começamos a nos bater com os balões. Um bebê também se aproximou e começou a bater na gente com um balão, então saí e os dois continuaram brincando. Combinamos em brincar de esconder, eu fui a primeira a fechar os olhos e contar até dez, mostrando como funcionava a brincadeira. Algumas crianças do GIV se escondiam e, com a ajuda da Camila, alguns bebês também. Mal comecei a procurar e as crianças já saíram correndo e gritando. Algumas crianças também fecharam os olhos e contaram, repetindo a brincadeira. (Relatório de intervenção GIV, 13/05/2008).

\section{Situaç̃̃o 2}

Ajudo-os a tirar os brinquedos de cima das prateleiras, fazendo o som que caracteriza cada bicho. Priscila começa a andar de quatro, imitando um cachorro, tentando envolver os bebês. Apenas um deles participa da brincadeira e logo desiste. Enquanto isso, a estagiária Ilha brinca com os bebês, rolando a bola um para o outro. Assim me sentei na roda e convidei as crianças do GIV para brincarem também. Três crianças sentam-se e brincaram de bola com os bebês. (Relatório de intervenção GIV, 14/05/2008)

\section{Situação 3}

Pedi para eles mostrarem os brinquedos aos bebês, Kauã Soares rapidamente pegou na mão de um bebê e começou a mostrar os brinquedos, levando o bebê para dentro da tenda, lá 
ele sentou com o menino e começou a lhe mostrar livros. Depois de algum tempo coloquei música (CD “O Circo”), e começamos a encher balões, que compramos para essa visita dos bebês. O professor de Ed. física pediu que as crianças fossem na tenda e começamos a jogar os balóes por cima da tenda, lá dentro as crianças brincavam e pulavam tentando pegar os balões, envolvendo todas as crianças. As crianças têm a idéia de fazer barriga de balão, e todas pedem um balão para colocar na barriga, eles adoram a brincadeira e riem de si mesmas e dos colegas, pedem para bater foto e mostram suas barrigas, as meninas passam a mão na barriga como se estivessem grávidas. As brincadeiras com balões aproximaram as crianças dos dois grupos que brincaram juntas e ficaram muito felizes. (Relatório de intervenção GIV, 14/05/2008)

Em muitas situações, a intervenção do adulto é muito importante para aproximar os dois grupos. Para incentivar essa interação, faz-se necessário ações planejadas e refletidas, para que essas não aconteçam de forma forçada, respeitando a individualidade e autonomia das crianças. Para Schimitt (2008, p.178), “O equilíbrio entre o cuidado e o respeito com liberdade dos bebês é algo que só poderá ser construído pela convivência, pela presença, pelas mediações dos adultos e pela percepção de todos que convivem nesse espaço."

Assim, com a nossa intervenção e com as brincadeiras, as crianças gradativamente foram ficando mais à vontade e interagindo mais. Entretanto, foi na hora do jantar, no espaço coletivo, que se pode perceber uma interação mais explícita em que as crianças do GIV deram comida para as do GII.

Algumas crianças ajudavam as outras e as sujavam, também conversavam com os bebês, perguntavam se estava gostoso, se queriam carne, e não entendendo o que os bebês queriam, eles insistiam com a comida. João, Kauã Carlos e Kaylane começaram a comer a comida dos bebês, explicamos que logo serviriam a janta deles e que ai sim poderiam comer. (Relatório de intervenção, 13/05/2008) 


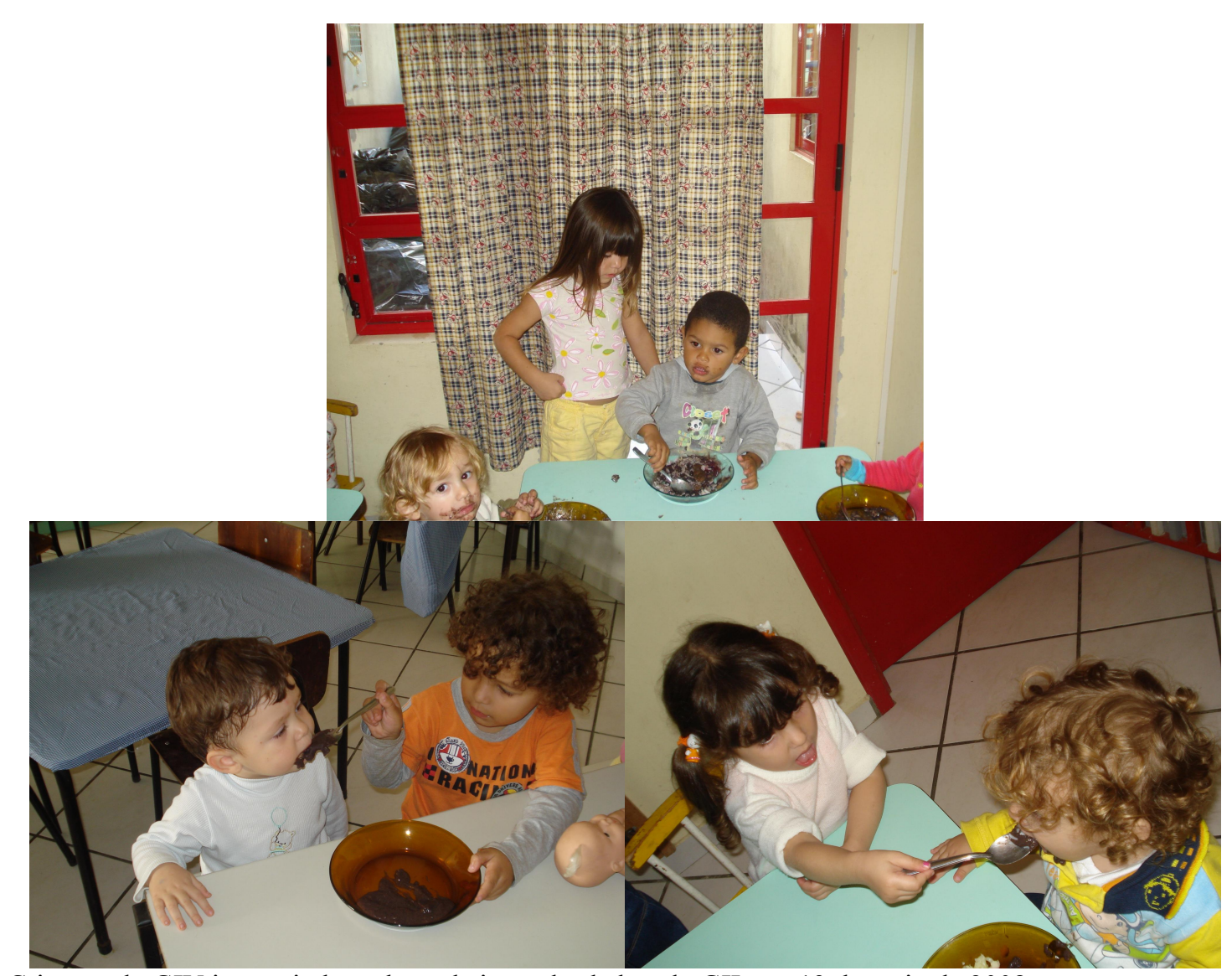

Crianças do GIV interagindo na hora da janta dos bebes do GII, em 13 de maio de 2008.

É interessante ressaltar que mesmo as crianças que não estavam ajudando ninguém, ficaram ali observando as outras, sentadas ao lado, dispostas a interagir naquele momento.

Quando se trata da relação entre o adulto e criança, percebe-se uma grande diferença, pois quando grupos de crianças vão brincar juntos, geralmente são aceitos rapidamente e autorizados a participarem da brincadeira. Já o adulto quando vai brincar junto sem ser convidado é ignorado pela criança, sendo que esse passa a ser aceito só a partir do momento que é convidado para brincar, e depois de ser convidado pela primeira vez, passa a estar autorizado a participar de outras brincadeiras em outros momentos. Assim aconteceu conosco, sendo que passamos a ser aceitas nas brincadeiras só depois de provar que também sabíamos brincar. Assim, gradativamente fomos conquistando a confiança das crianças, ouvido-as e respeitando os seus pontos de vista.

Intentamos não obrigar as crianças a nada, sempre mostrando o quão interessante seria realizar cada atividade proposta. Não diminuindo, assim, o respeito que elas tinham por nós. Quando víamos que as crianças agiam de forma que pudessem 
prejudicar o grupo ou a si mesma, tentávamos mostrar que isso não era a melhor coisa a fazer e o motivo disso. Assim, compreendendo o motivo, geralmente aceitavam as sugestões dadas pos nós.

Durante as atividades, as crianças antes de começarem a fazer qualquer coisa esperavam por algum tipo de aprovação, como aconteceu no dia de brincar de circo, em que algumas ficaram paradas olhando, sem saber o que fazer e o mesmo aconteceu no dia da pintura do grande tecido e também quando elas nos pintaram de bruxa.

Após fazerem o lanche e a higiene, pedimos para as crianças irem brincar no parque, dizendo que lá elas teriam uma surpresa. Vestimos-nos com trajes de bruxa e sentamos em uma parte isolada do parque. A educadora avisou para as crianças que lá estava a surpresa, elas correram e ficaram nos olhando sem saber o que estava acontecendo, algumas olhavam de longe, outras foram chegando mais perto. Entregamos uma caixa com maquiagem a elas e dissemos que poderiam nos maquiar como bruxas, então, todas se aproximaram. Junto com as crianças do $\boldsymbol{G I V}$ estavam crianças do $\boldsymbol{G I I I}$, que também nos quiseram nos maquiar. (Relatório de intervenção GIV, 19/05/2008)

Neste momento citado a cima, fica claro que as crianças esperaram nossa aprovação para realizarem tal atividade, e após perceberem que poderiam ficar a vontade, elas começaram a utilizar as maquiagens de todas as formas, experimentando os diversos produtos, nos pintando, pintando os colegas e pintando a si próprios.

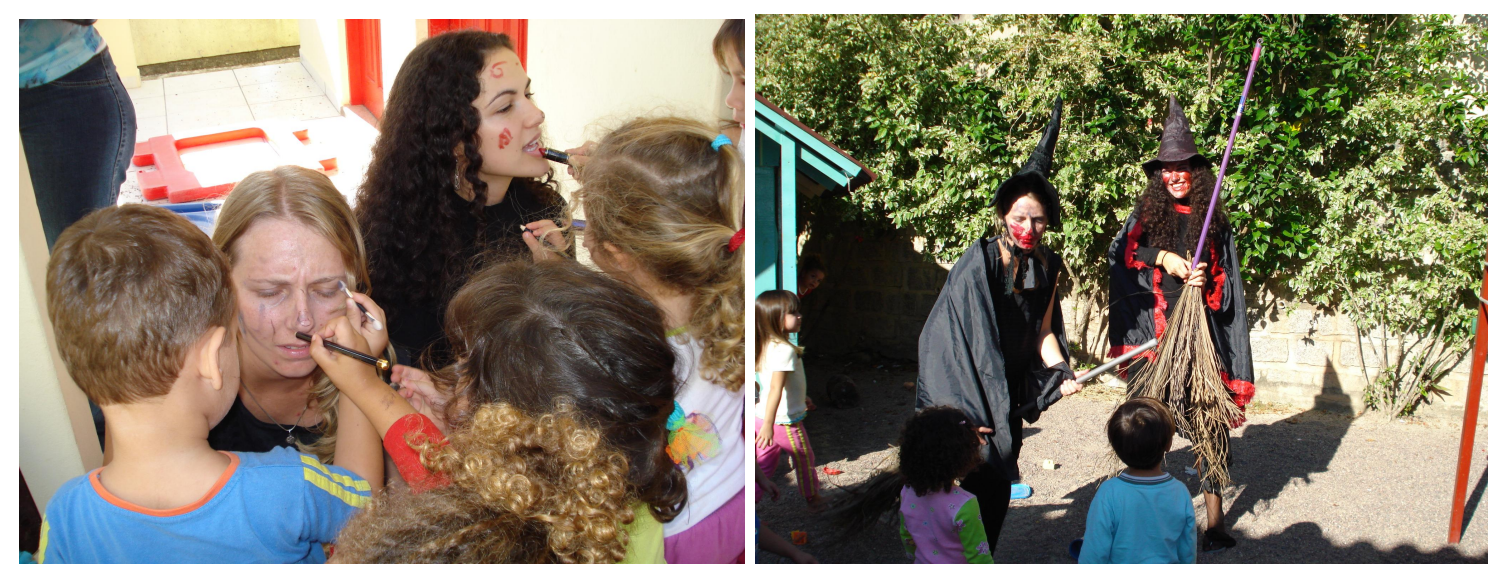


Crianças maquiando as estagiárias e brincando de bruxa, em: 19 de maio de 2008.

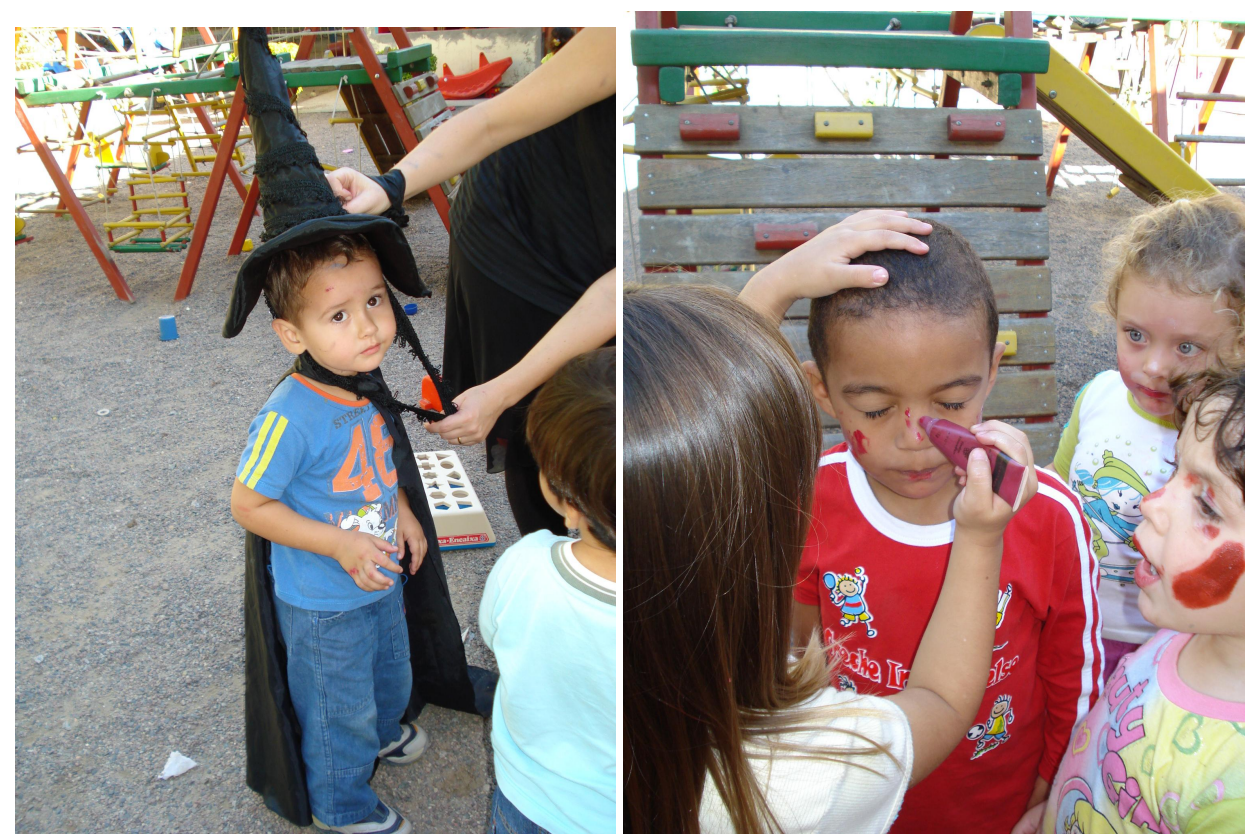

Brincando com as fantasias das bruxas e maquiagens, em: 19 de maio de 2008.

\subsection{As marcas do estágio}

Durante nossa intervenção procuramos diversificar as atividades, trazendo um novo repertório de brincadeiras para, a partir do que apresentamos, estimular a criatividade das crianças. Pois, na observação das mesmas, percebemos que esse repertório de brincadeira mostrava-se um tanto quanto limitado.

Assim, além das atividades do projeto que tinham como tema o circo, preparamos diversas brincadeiras baseadas em contos de fadas - envolvendo personagens como Chapeuzinho Vermelho, Os Três Porquinhos, o Lobo Mau e a Bruxa. Trazendo, ainda, jogos populares como: O Mestre Mandou, Coelhinho Sai da Toca, Morto-Vivo, Pular Corda, dentre outros.

Já nas atividades planejadas, além de brincar, as crianças puderam vivenciar momentos de construção de novos espaços para suas brincadeira. Como foi o caso da produção da tenda do circo, que resultou em um livro de história feita por elas, contando todo o processo dessas vivencias. 


\subsubsection{A tenda de circo}

Como trabalharíamos num projeto sobre o "Circo Colorido", preocupamo-nos em oferecer um espaço lúdico, que incentivasse a fantasia e o brincar. Mas este espaço, além de proporcionar a ludicidade, deveria também, ser reconhecido como próprio do grupo, que tivesse as marcas das crianças, para assim, reforçar as suas identidades.

Coletivamente temos de fazer o esforço de pensar formas genuínas de as crianças participarem, interferirem, influenciarem no espaço da instituição de educação infantil, para que possam oportunizar-lhes efetiva participação, contando com as suas contribuições para enriquecermos os espaços destinados à educação da infância com a imaginação, inventividade e ludicidade próprias das mesmas. A apropriação do espaço pelas crianças supõe que estás possam colocar suas marcas, alterá-lo, transformá-lo, imprimindo seus registros nas paredes, portas, janelas, tetos, chão, por toda a instituição, personalizando-a. (AGOSTINHO, 2005, p. 65).

Nesse sentido, pensamos que construir um circo dentro da sala poderia contemplar todos essas questões. Assim, o primeiro passo foi planejar como poderíamos fazer a estrutura da tenda, para depois comprar os materiais necessários. O segundo foi a pintura do tecido, uma atividade em que as crianças tinham clareza da intenção, pois, sabiam que estavam ajudando a construir uma tenda de circo para poderem brincar nela.

Essa atividade proporcionou uma experiência muito significativa para as crianças e também para nós, pois elas puderam experimentar outra forma de trabalho com pintura. E tiveram a liberdade de pintarem um tecido de grande proporção, usando diversas cores de tinta, sem a preocupação de se sujarem, ou misturar as tintas, podendo usar a quantidade e a maneira que a criatividade permitisse.

As crianças puderam usar todos os sentidos, pintando com pinceis, mãos, pés, com todo o corpo, podendo sentir as texturas, a temperatura. Pintando, conversando, cantando e dançado, ao som de músicas de circo. A alegria e satisfação das crianças marcaram aquele dia, pois puderam viver plenamente aquele momento.

Em terceiro lugar, iríamos confeccionar objetos para enfeitar a tenda, como almofadas e móbiles. Assim, como tínhamos que contemplar o conteúdo das formas geométricas, levamos tecidos com desenhos geométricos, para serem pintados pelas crianças, com o objetivo de fazer almofadas para a tenda. Desta vez, optamos pelo 
trabalho com duplas, sendo que, enquanto uma dupla pintava as formas com pinceis, as outras brincavam livremente no parque pequeno.

Nesta atividade, percebemos grande concentração das crianças, já que pedimos para pintarem cada forma geométrica de uma cor determinada, e apenas dentro das formas, e não o tecido inteiro. Assim, podemos dar uma atenção maior para cada criança. Enquanto pintavam, conversávamos sobre as cores e formas. Nesse momento, duas crianças saíram para conferir se o céu era realmente azul, e se algumas plantas eram verdes, e, assim, satisfeitas, voltaram para sala confirmando a hipótese e continuaram pintando.

No dia seguinte, trouxemos recortes retangulares de cartolina com desenhos geométricos feitos com giz de cera branco, deixando o desenho quase invisível. Desta vez, a pintura foi ao ar livre, com tinta aquarela. Nesta atividade, falamos que quando elas pintassem a cartolina, aconteceria uma mágica. Então, no decorrer das pinturas, as crianças fascinadas, comentavam sobre a mágica que estava acontecendo, mostrando as formas que surgiam para os colegas. Depois, com as cartolinas secas, as crianças ajudaram na montagem dos móbiles, furando as cartolinas, cortando e amarrando as fitas para juntar os recortes de cartolina.

Neste mesmo dia, levamos para casa, os tecidos das almofadas e o da tenda para serem costurados, para as crianças encherem no dia seguinte, com esponjas. Com a tenda e os materiais de enfeite prontos, as crianças puderam desfrutar daquele novo espaço, que oferecia enumeras possibilidades. Essa passou a ser usada para brincadeiras, esconderijo, conversas, ler histórias, para ver vídeos, e ainda, para descansar. Alguns destes momentos podem ser visualizados, conforme registro fotográfico que apresentamos a seguir:

\section{Pintura do grande tecido}
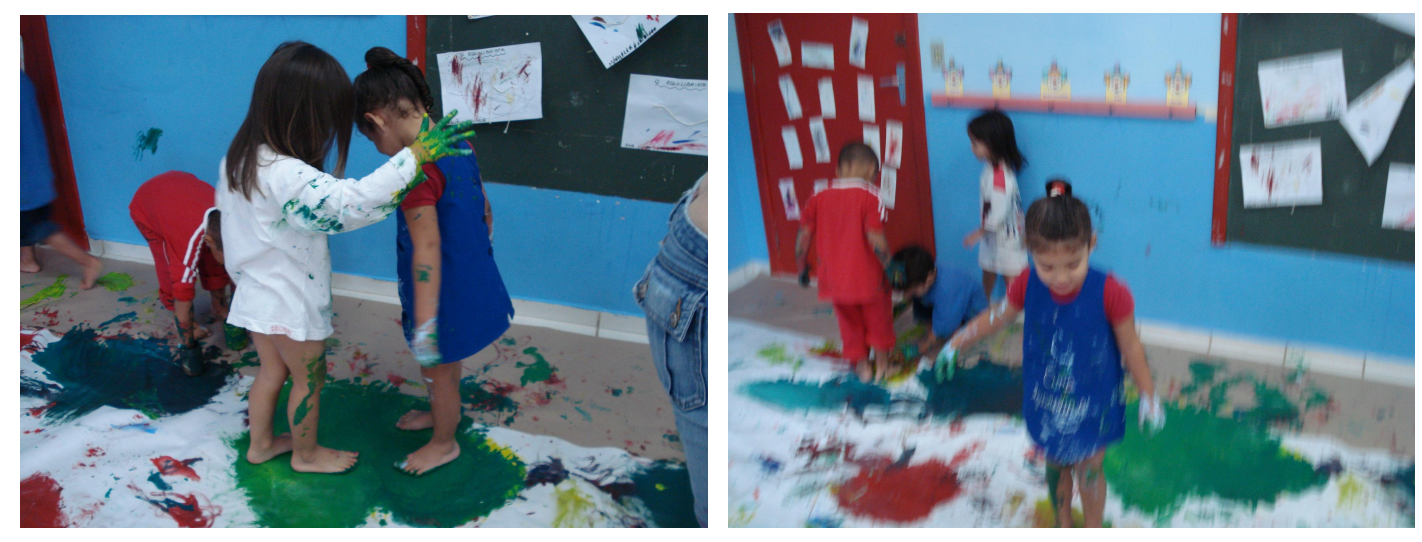


\section{Confecção das almofadas}
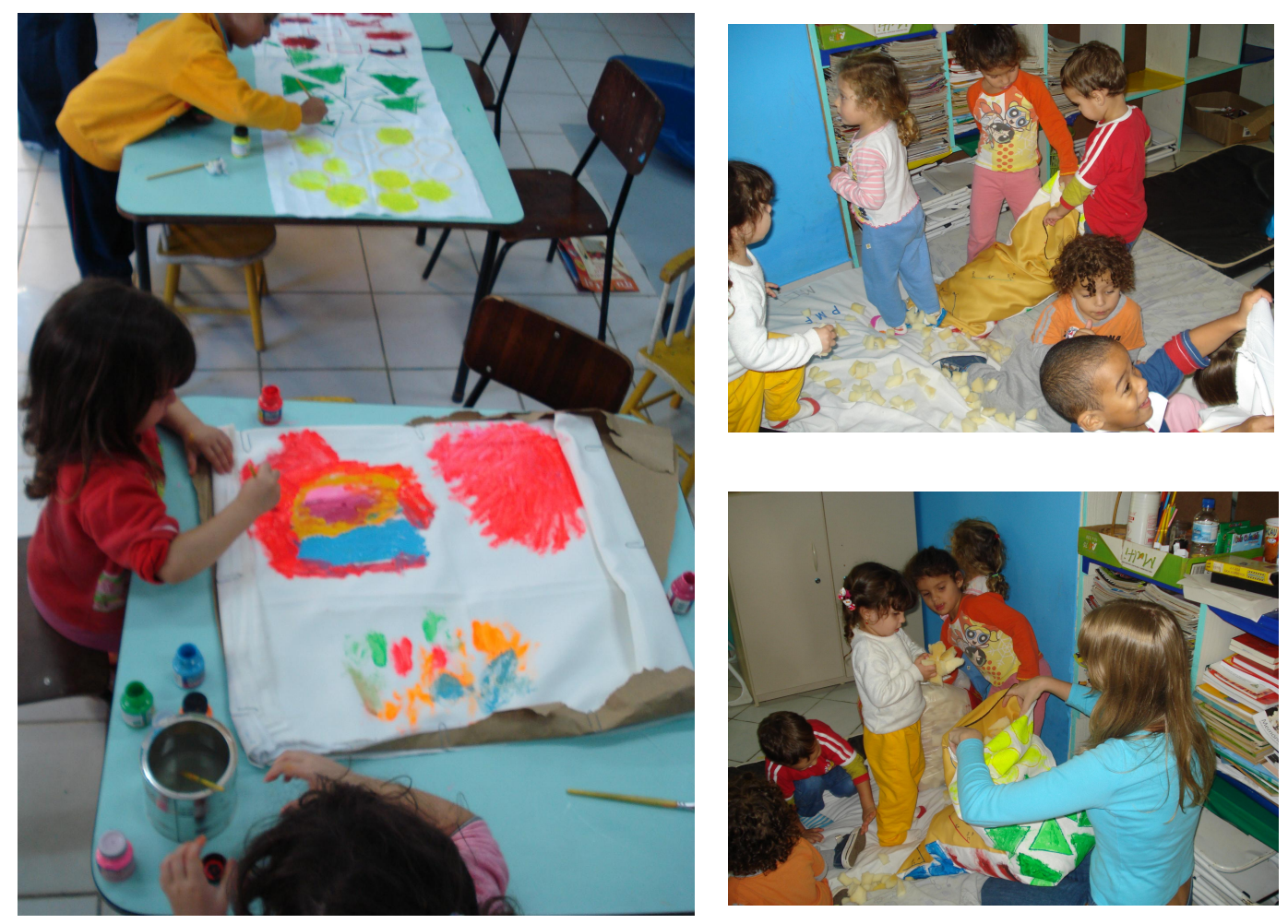

\section{Confecção dos móbiles}
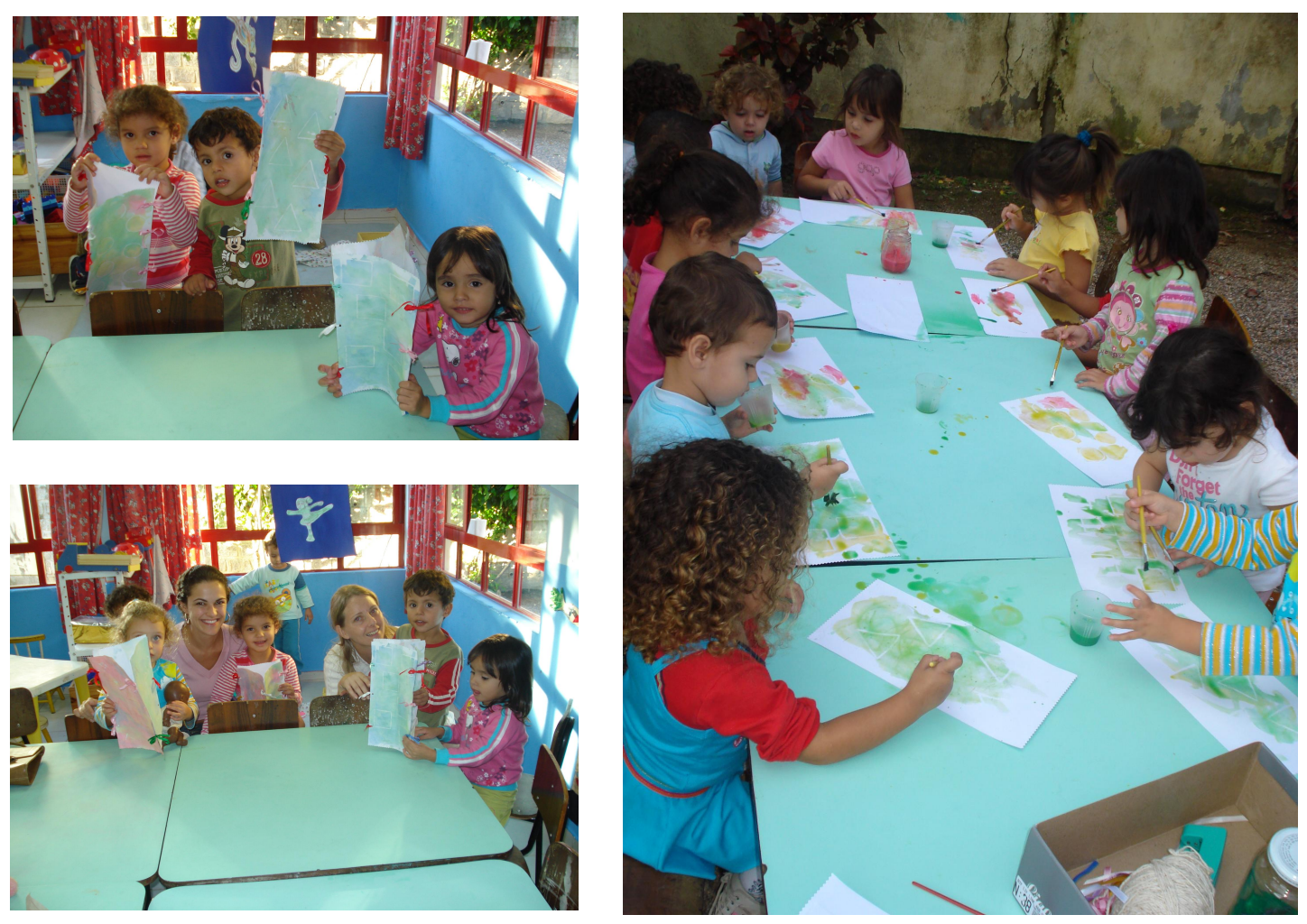


\section{Brincando de circo}
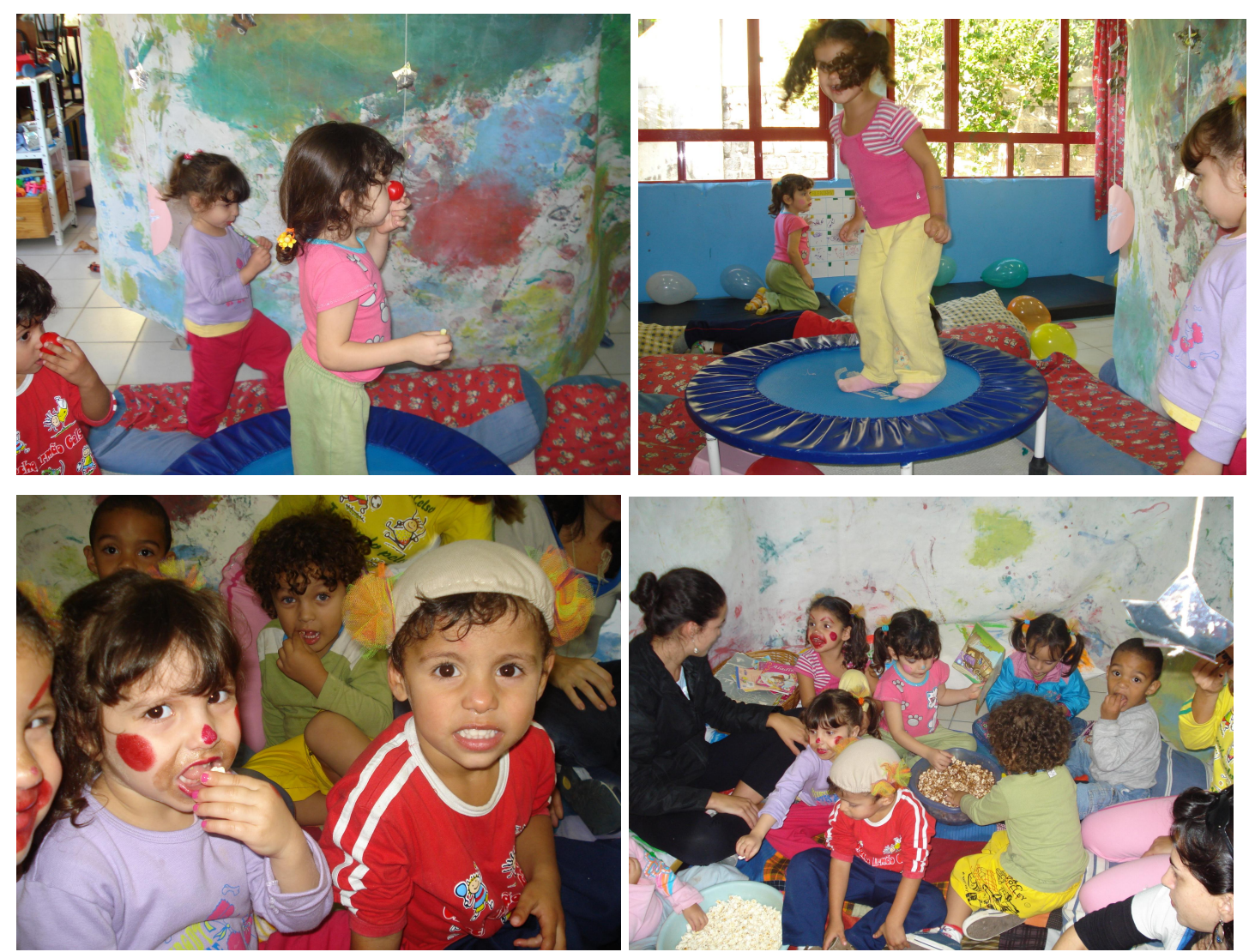

\subsubsection{A Confeç̧ão do Livro}

Ao buscar uma forma de registrar todos os momentos de preparo da tenda de circo e outros objetos, pensamos em fazer um livro com a história contada pelas crianças, que contemplassem todas as vivencias no decorrer do nosso projeto. Tivemos todo o cuidado para que esse livro pudesse ter a identidade do grupo, para que esses pudessem se reconhecer ao folhear o livro.

Sentados dentro da tenda, explicamos que iríamos conversar sobre nossas vivencias, e registrar tudo, para fazer um livro. Então, aos poucos, íamos fazendo perguntas para as crianças, a fim de relembrar os momentos que passamos juntos, quando pintamos a tenda, fizemos os móbiles e as almofadas.

Com o registro das memórias das crianças, organizamos um livro, com imagens prontas que lembravam circo. Fizemos isso para que quando as crianças olhassem o livro pudessem fazer uma leitura dos desenhos, associando-os com as vivencias. 
Lemos a história para as crianças, mostrando os desenhos, e assim elas puderam escolher qual gostariam de pintar. Entregamos giz de cera colorido, e deixamos que elas pudessem pintar livremente. Mesmo sabendo que muitos autores e educadores são contrários em fazer atividades utilizando materiais que não são feitos pelas crianças no caso específico desta nossa intervenção, o desenho fotocopiado -, isso não desmereceu o trabalho, que continuou com a cara das crianças. Pois elas puderam pintar os desenhos livremente, fazendo uma reapropriação dos mesmos.

Com os desenhos já pintados, fizemos junto com as crianças a capa do livro, permitindo que elas observassem e ajudassem em todas as etapas. As crianças ficaram super atentas e interessadas em ajudar, querendo participar de todos os processos.

O livro foi algo muito significante em nosso estágio, pois permite que se relembre toda a história da tenda, de uma forma fácil e prazerosa, podendo servir para as crianças, pais e funcionários da creche, e para que todos que não a vivenciaram possam conhecê-la.

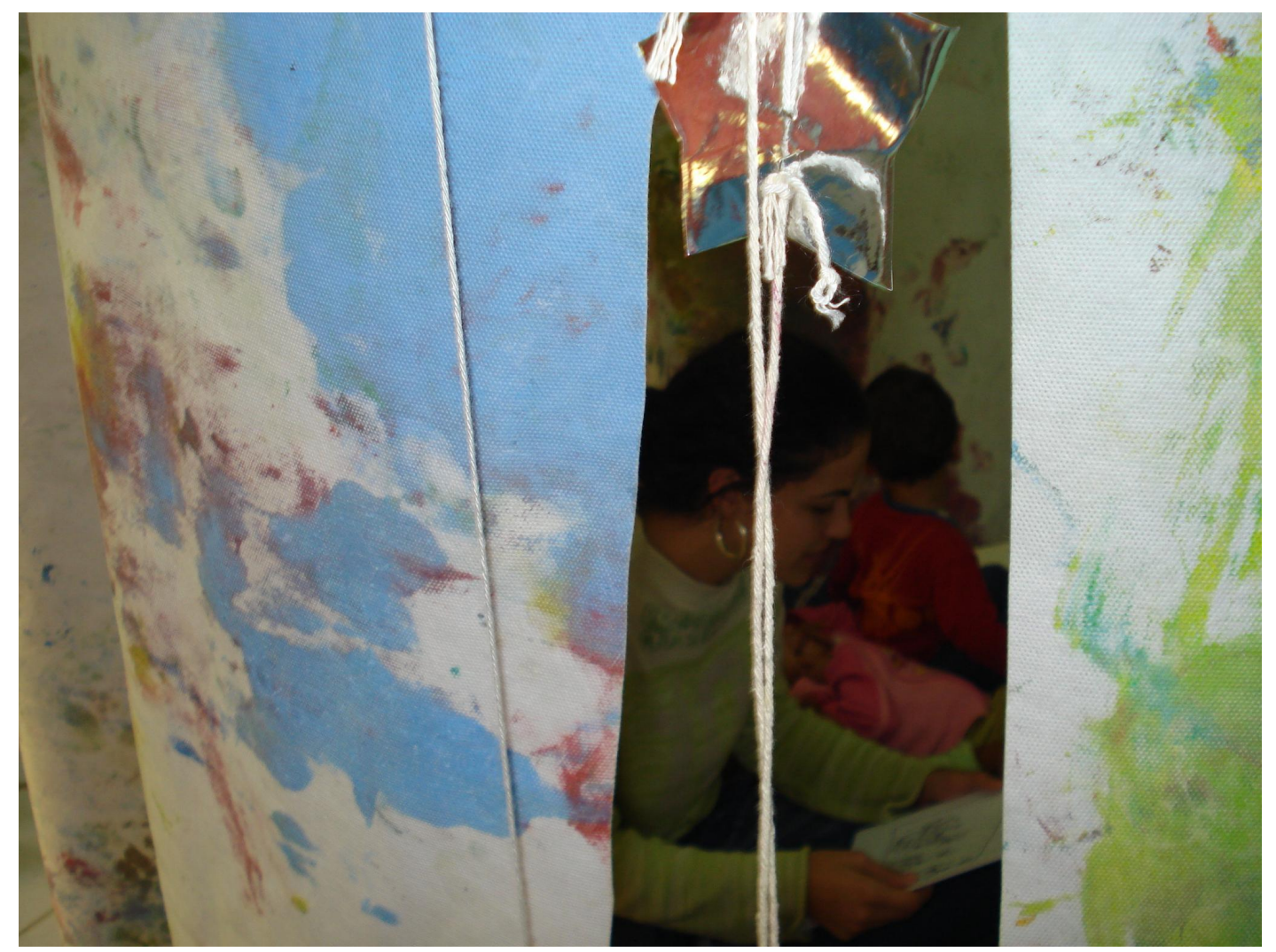

Dentro da tenda, leitura da história feita pelas crianças, em 14 de maio de 2008. 


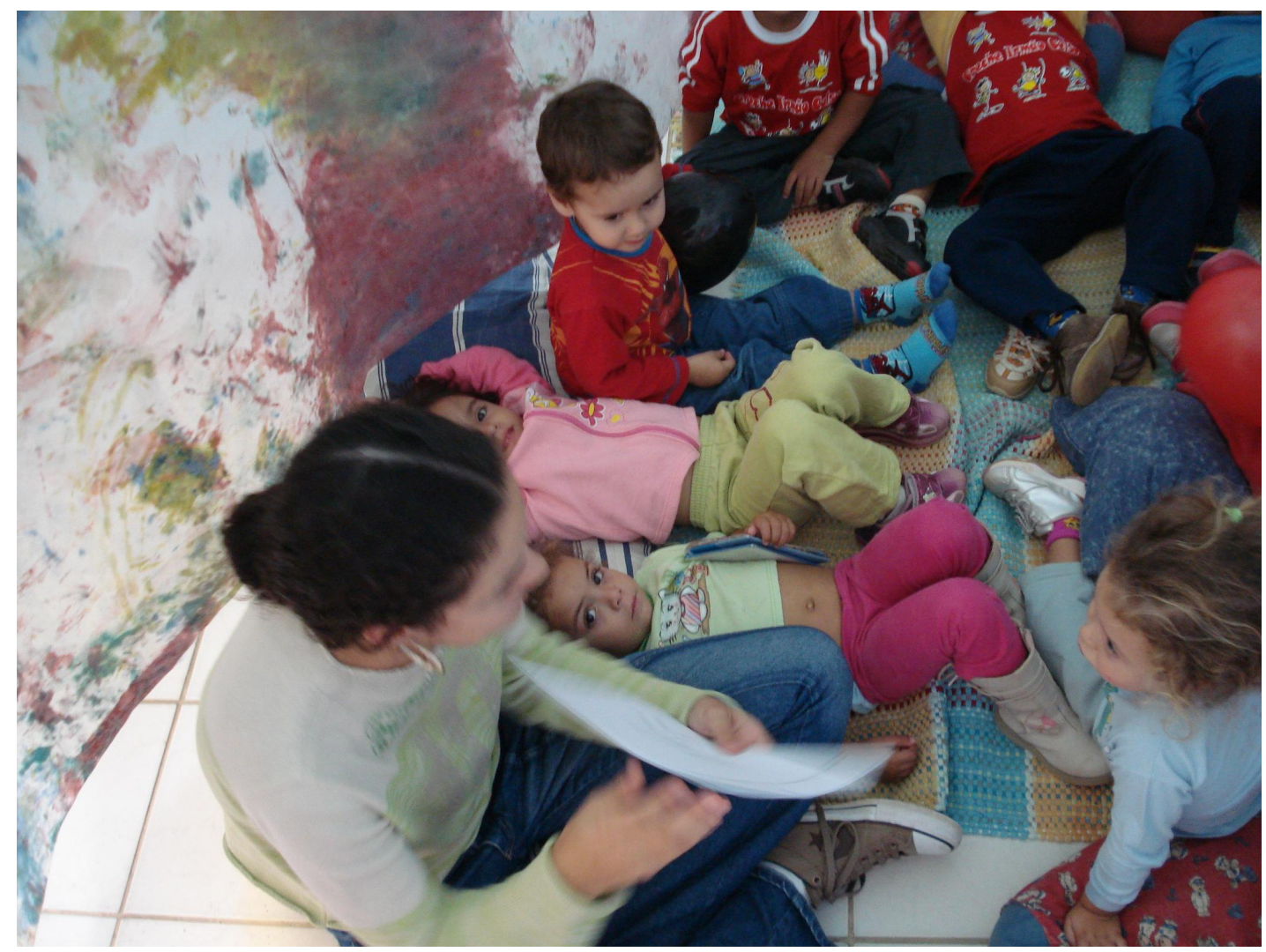

Dentro da tenda, leitura da história feita pelas crianças, em: 14 de maio de 2008.

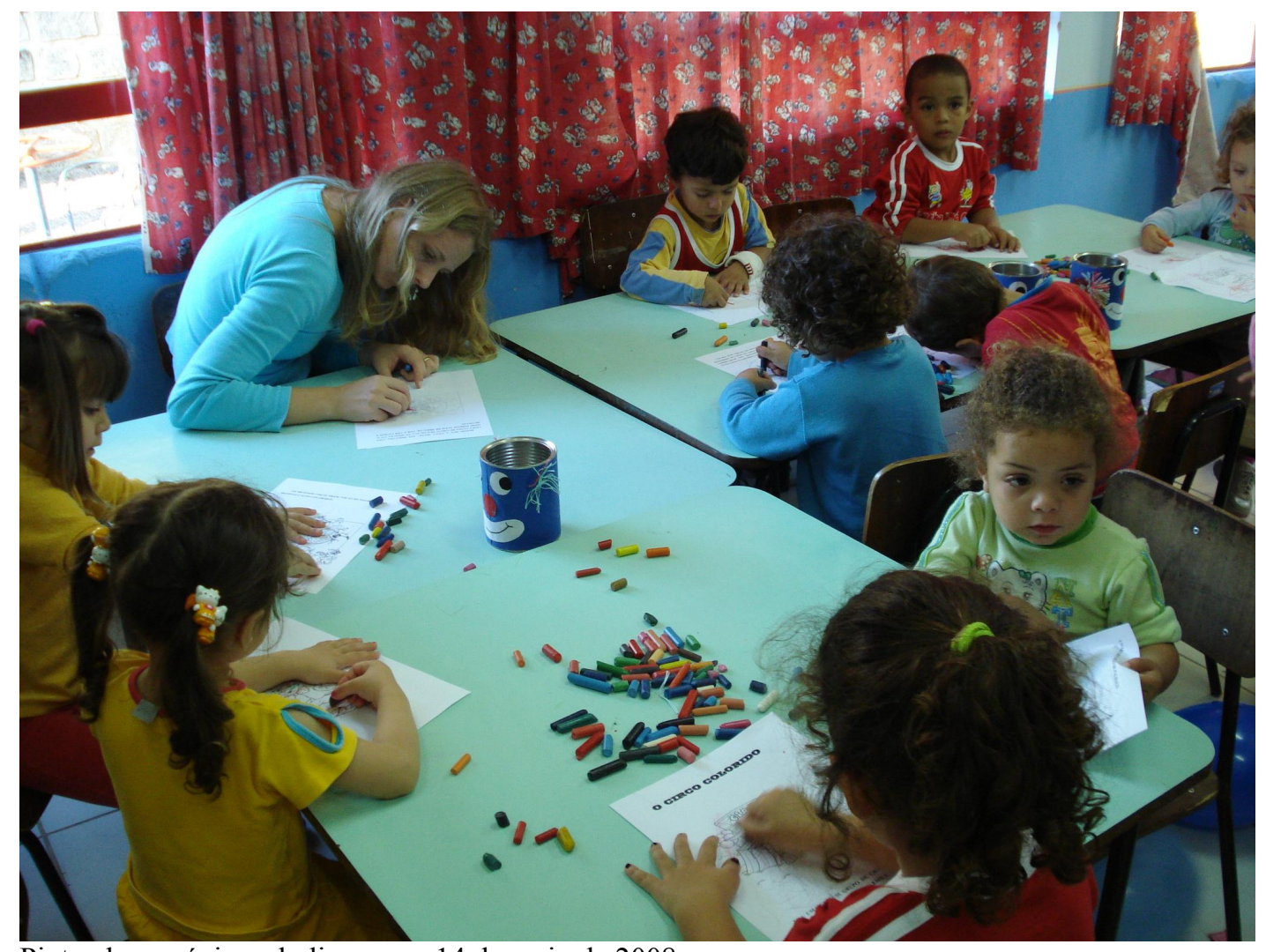

Pintando as páginas do livro, em: 14 de maio de 2008. 


\section{CONCLUSÃO}

O estágio em educação infantil foi fundamental para nosso crescimento intelectual e profissional, pois nos permitiu observar aspectos da educação infantil que até então conhecíamos apenas na teoria. A prática nos permitiu entrar em contato com as inúmeras dificuldades que passam os profissionais da área.

Durante esse estágio, pudemos perceber as limitações encontradas pelos educadores para conseguirem oferecer diversas atividades que contemplem os direitos das crianças. Nesse sentido, um planejamento exige tempo, para que esteja apoiado em pesquisa, observação e reflexão, o que nos foi proporcionado no estágio. Após terminarmos o nosso planejamento, buscamos saber quais os materiais que a instituição já possuía. Essa foi o primeiro obstáculo encontrado, pois a creche possuía poucos dos materiais que necessitávamos para realizar as atividades planejadas. Assim, tivemos que sair em busca dos materiais, o que demandou tempo e dinheiro. O terceiro foi a colaboração dos funcionários da creche, que se encontravam limitados pelos horários a serem cumpridos e também por não compreenderem as intenções de muitas atividades, o que nos constrangia, por que diversas vezes pareciam achar desnecessário a "bagunça" feita na sala.

Portanto, se nós, como estagiárias, intervindo três vezes por semana, já encontramos dificuldades em planejar e preparar as atividades ponderamos sobre quão difícil é trabalhar em dois períodos e durante toda a semana. Entendemos então, que os educadores deveriam ter direito há um tempo determinado para fazer seus planejamentos, e para terem também, a possibilidade de interagir com os educadores de outras salas para que possam listar os materiais necessários para realizarem as intervenções, pois percebemos que a creche possui grande quantidade de materiais, porém, pouca variedade. Assim, com o dinheiro reservado para compra de materiais poderia ser mais bem aplicado, comprando materiais diferentes, para que esses possam ser comprados de acordo com as necessidades das atividades planejadas, e não o contrário, em que as atividades precisam ser planejadas segundo os materiais que a creche possui.

Todos que trabalham nas instituições de educação realizam papel de educadores, assim, precisam estar constantemente realizando reuniões para que cada um possa entender as propostas dos outros, para que educadores saibam os limites dos 
funcionários e os funcionários saibam as necessidades, e o porquê das propostas trazidas pelas educadoras, e passem a ajudar na organização dos espaços e tempos.

\section{REFERÊNCIAS}

AGOSTINHO, Kátia Adair. Creche e pré-escola é "lugar" de criança. In: MARTINS FILHO, José (Org.). Criança pede respeito: temas em educação infantil. Porto Alegre: Mediações, 2005. p. 63-75.

CARVALHO, Mara Campos de \& MENEGHINI, Renata. Estruturando a sala: interações na creche mudam dependendo da área espacial. In: ROSSETTI-FERREIRA, Maria Clotilde et all (Orgs.) Os fazeres na educação infantil. $5^{\text {a }}$ Ed. São Paulo: Cortez, 2002. p. 150-152.

CARVALHO, Mara I. de \& RUBIANO, Márcia R. Bonagamba. Organização do espaço em instituições pré-escolares. In: OLIVEIRA, Zilma de Moraes Ramos de (Org.) Educação Infantil: muitos olhares. 2ª ed. São Paulo: Cortez; 1995. p. 107-130.

FERREIRA, Manuela. Do "avesso" do brincar ou... as relações entre pares, as rotinas da cultura infantil e a construção da(s) ordem(ens) social(ais) instituinte(s) das crianças no jardim-de-infância. In: Sarmento, M. J. \& Cerisara, A. B. (Eds.), Crianças e miúdos, perspectivas sócio pedagógicas na infância e educação. Porto, Edições ASA, 2004. p. 55-104.

KRAMER, Sônia et all. Com a pré-escola nas mãos: uma alternativa curricular para a educação infantil. $7^{a}$ Ed. São Paulo: Ática, 1994.

MACHADO, Maria Lucia de A. Por uma pedagogia da educação infantil. Pátio Educação Infantil. Porto Alegre: Artmed, ano 2, n. 5, ago./nov. 2004. p. 6-8

OSTETTO, Luciana E. (org.). Encontros e encantamentos na educação infantil: Partilhando experiências de estágios. - Campinas, SP: Papirus, 2000. p. 175-199

PRADO, P.D. (Org.). Por uma cultura da infância: metodologias de pesquisa com crianças. Campinas: Autores Associados, 2002, p. 106.

SERRÃO, Célia Regina Batista. O tempo na educação infantil: rotinas. In: NICOLAU, M. L. M. \& DIAS, M. C. M. (Org.). Oficinas de sonhos e realidades na formação do educador da infância. Campinas-SP: Papirus, 2003. p. 25-36.

SCHMITT, Rosinete Valdeci. "Mas eu não falo a língua deles!": As relações sociais de bebês num contexto de educação infantil. Florianópolis, abril de 2008.

WAJSKOP, Gisele. Brincar pré-escolar. $4^{\circ}$ Ed. Editora Cortez, 2001. p. 19-75 